\title{
Historia de un campamento del Horizonte Medio de Huarmey, Perú (PV35-4)
}

Histoire d'un campement de l'Horizon Moyen à Huarmey, Pérou (PV35-4)

History of a Middle Horizon campsite in Huarmey, Peru (PV35-4)

Duccio Bonavia, Alexander Grobman, Laura W. Johson-Kelly, John G.

Jones, Ynés R. Ortega, Raúl Patrucco, Alberto Pumayalla D., Elizabeth J. Reitz, Raúl Tello, Glendon H. Weir, Elizabeth S. Wing y Angel Zárate Zavaleta

\section{(2) OpenEdition}

\section{Edición electrónica}

URL: http://journals.openedition.org/bifea/2636

DOI: $10.4000 /$ bifea.2636

ISSN: 2076-5827

Editor

Institut Français d'Études Andines

Edición impresa

Fecha de publicación: 1 agosto 2009

Paginación: 237-287

ISSN: 0303-7495

Referencia electrónica

Duccio Bonavia, Alexander Grobman, Laura W. Johson-Kelly, John G. Jones, Ynés R. Ortega, Raúl Patrucco, Alberto Pumayalla D., Elizabeth J. Reitz, Raúl Tello, Glendon H. Weir, Elizabeth S. Wing y Angel Zárate Zavaleta, « Historia de un campamento del Horizonte Medio de Huarmey, Perú (PV35-4) », Bulletin de I'Institut français d'études andines [En línea], 38 (2) | 2009, Publicado el 01 febrero 2010, consultado el 17 noviembre 2020. URL : http://journals.openedition.org/bifea/2636 ; DOI : https://doi.org/10.4000/bifea.2636

\section{(c) $(1)$}

Les contenus du Bulletin de l'Institut français d'études andines sont mis à disposition selon les termes de la licence Creative Commons Attribution - Pas d'Utilisation Commerciale - Pas de Modification 4.0 International. 


\title{
Historia de un campamento del Horizonte Medio de Huarmey, Perú (PV35-4)
}

\author{
Duccio Bonavia', Alexander Grobman2, Laura W. Johson- \\ Kellyz, John G. Jones, Ynés R. Ortega5, Raúl Patrucco6, Alberto \\ Pumayalla D.7, Elizabeth J. Reitzi, Raúl Tello", Glendon H. \\ Weir 10, Elizabeth S. Wing ${ }^{11}$, Angel Zárate Zavaleta12
}

\begin{abstract}
Resumen
Se presenta el estudio de un campamento temporal del Horizonte Medio situado en el desierto costero peruano al norte del valle de Huarmey. Se ha excavado la parte central del mismo pues presentaba la mayor cantidad de basura y dos fogones. Se ha podido establecer a base de la cerámica encontrada, que el sitio corresponde al Horizonte Medio 3. Los artefactos hallados son muy pocos, lo que es lógico dada la corta ocupación del sitio. Sin embargo se ha podido estudiar los abundantes restos botánicos y animales así como los fecales de llama que estaban acumulados en el lugar. También se ha encontrado coprolitos humanos. De ambos se ha realizado el examen polínico. Además de los excrementos humanos se ha efectuado el análisis del contenido de plantas y animales así como el parasitológico.
\end{abstract}

Palabras clave: arqueología peruana, Horizonte Medio, Huarmey, etnobotánica, arqueozoología, parasitología

1 Academia Nacional de la Historia. Casilla 18-0194, Lima 18, Perú. Realizó el trabajo de campo, el estudio de los restos culturales y los análisis malacológicos. Es además el autor de la discusión. E-mail: dbonavia@terra.com.pe

2 Profesor Emérito de la Universidad Nacional Agraria, La Molina, Lima, Perú. Hizo el estudio del maíz.

3 Herbert F. Johson Musem of Art, Cornell University, Ithaca, NY 14853, U.S.A. Estudió el material botánico.

4 Department of Anthropology, Washington State University.PO Box 644910. Pullman, WA 991644910. U.S.A. Se encargó del estudio de los coprolitos animales.

5 Center for Food Safety and Department of Food Sciences and Technology, University of Georgia, Griffin, Georgia 30223. U.S.A. Realizó el estudio de parasitología en los coprolitos humanos.

6 + Laboratorio de Inmunología e Instituto de Medicina Tropical Alexander von Humboldt, Universidad Peruana Cayetano Heredia, Lima, Perú. Llevó a cabo los análisis parasitológicos de los coprolitos humanos. 


\title{
Histoire d'un campement de l'Horizon Moyen à Huarmey, Pérou (PV35-4)
}

\section{Resumé}

Cet article étudie un campement temporaire de l'Horizon Moyen situé dans le désert côtier péruvien au nord de la vallée de Huarmey. La partie centrale du site a été choisie pour les fouilles car elle offrait la plus grande quantité de déchets ainsi que deux foyers. II a été établi que le site correspondait à l'Horizon Moyen 3 grâce à la céramique qui y fut trouvée. Peu d'outillage a été trouvé en raison de la courte occupation du site, mais les restes abondants d'animaux et botaniques ainsi que les restes fécaux de llamas et humains accumulés sur le site ont fourni de précieuses indications. Les résultats des examens polliniques des coprolithes ainsi que les analyses du contenu de plantes, animaux et parasytes présents dans les coprolithes humains sont présentés ici.

Mots clés: archéologie péruvienne, Horizon Moyen, Huarmey, ethnobotanique, archéozoologie, parasitologie

\section{History of a Middle Horizon campsite in Huarmey, Peru (PV35-4)}

\begin{abstract}
This is a study of a Middle Horizon temporary campsite located in the peruvian north coastal desert of the Huarmey Valley. The excavation was undertaken in the central part of the site since it contained the largest quantity debris and evidence of two bonfires. Its age was established using pieces of ceramic found on the site. A few artifacts were founded, probably due to the brief occupancy of the site, but were able to study the abundant botanical and animal remains, as well as llama and human coprolites. We present the results of tests for pollen in both the llama and human coprolites, as well as of tests for plant, animal, and parasite content in the human fecal remains are presented here.
\end{abstract}

Key words: peruvian archaeology, Middle Horizon, Huarmey, ethnobotany, archaeozoology, parasitology

7 + Laboratorio de Fibras Animales, Programa de Ovinos y Camélidos, Facultad de Zootecnia, Universidad Nacional Agraria, La Molina, Lima, Perú. Hizo el estudio y la identificación de las fibras de lana de alpaca.

8 Natural History Museum y Department of Anthropology \& Linguistics, The University of Georgia, Athens, GA30602-1882. U.S.A. Colaboró con Wing en el estudio de los restos animales.

9 Cuando se realizó el estudio formaba parte del Instituto de Medicina Tropical Alexander von Humboldt, Universidad Peruana Cayetano Heredia, Lima, Perú. Colaboró en el análisis parasitológico de los coprolitos humanos.

10 Cuando se llevó a cabo la investigación era profesor del Department of Anthropology, Texas A \& M University, College Station. U.S.A. Llevó a cabo el análisis de los coprolitos humanos con énfasis en la reconstrucción de la dieta y el análisis polínico.

11 Florida Museum of Natural History, University of Florida. Gainesville FL 32611-7800.U.S.A. Llevó a cabo el estudio de los restos animales.

12 Laboratorio de Fibras Animales, Programa de Ovinos y Camélidos, Facultad de Zootecnia, Universidad Nacional Agraria, La Molina, Lima, Perú. Colaboró con A. Pumayalla en el análisis de las fibras de lana de alpaca. 


\section{HISTORIA Y DESCRIPCIÓN DEL SITIO}

El yacimiento PV35-4 fue descubierto en diciembre de 1976 durante los trabajos que estaba realizando el Proyecto Arqueológico Huarmey en el área. En este artículo presentamos un mapa parcial de la zona con la ubicación del sitio (fig. 1). Para mayores detalles remitimos al lector al informe que hemos publicado sobre Los Gavilanes (Bonavia,1982: Mapa 2 [14-15], 417).

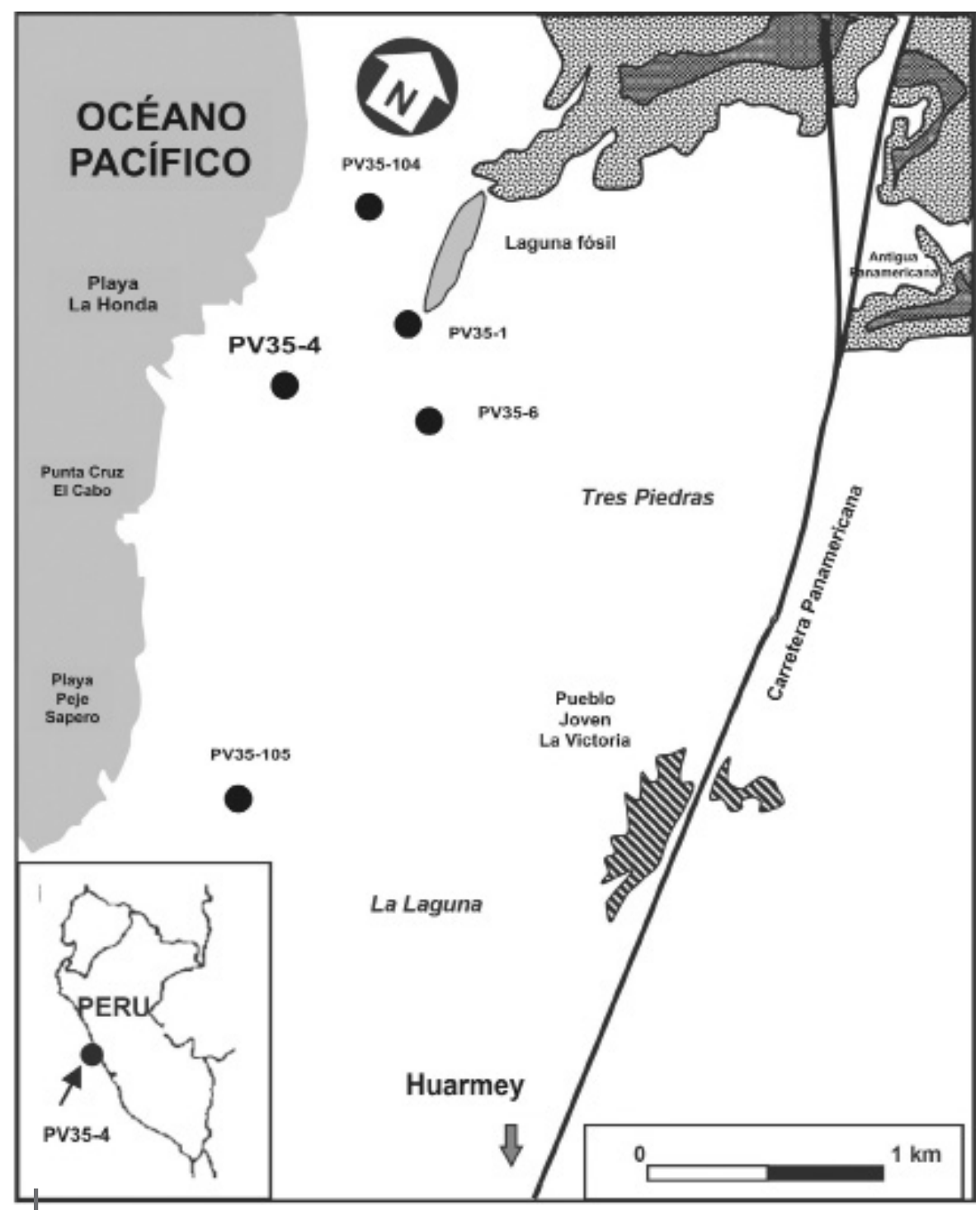

Figura 1 - Mapa de la zona con la ubicación del sitio

Mapa elaborado por Elmo León 
El sitio se encuentra en los arenales al norte del valle de Huarmey, en el departamento de Ancash (provincia y distrito de Huarmey). Está situado en la hoyada que desde Los Gavilanes lleva a la playa entre Playa La Honda y Punta Cruz el Cabo (vide Bonavia, 1982: Mapa 2,14-15) y conocida por los lugareños como Huanchaquito. Dista del mar poco más de $600 \mathrm{~m}$. La situación exacta es a $224^{\circ}$ (Azimut corregidos) tomados desde la cota de referencia del plano de Los Gavilanes (Bonavia, 1982: Plano 1, 20-21).

Se trata de un pequeño campamento situado en la mencionada hoyada, que es un pasaje natural entre la Pampa de Tres Piedras y la playa Huanchaquito. Es una zona que no tiene protección de los vientos y que como lugar de habitación está muy mal situada. El viento que llega desde el mar corre en este pasaje y de allí se dirige directamente a la Pampa Tres Piedras pasando por el yacimiento precerámico de Los Gavilanes (fig. 2).

El sitio está situado sobre la falda noroeste del cerro que forma este pasaje natural en la parte septentrional. Durante nuestra estadía en Los Gavilanes transitamos muchas veces por allí y si bien en la superficie no había restos culturales claros, nos llamaron la atención algunas conchas concentradas en una zona y unas leves manchas negras que resultaron ser de carbón. No cabe duda que el yacimiento estaba intacto y hasta nuestra llegada no había sufrido ningún tipo de deterioro. Su extensión es de $11 \mathrm{~m}$ de largo (en el sentido de la falda del cerro) por $5 \mathrm{~m}$ de ancho.

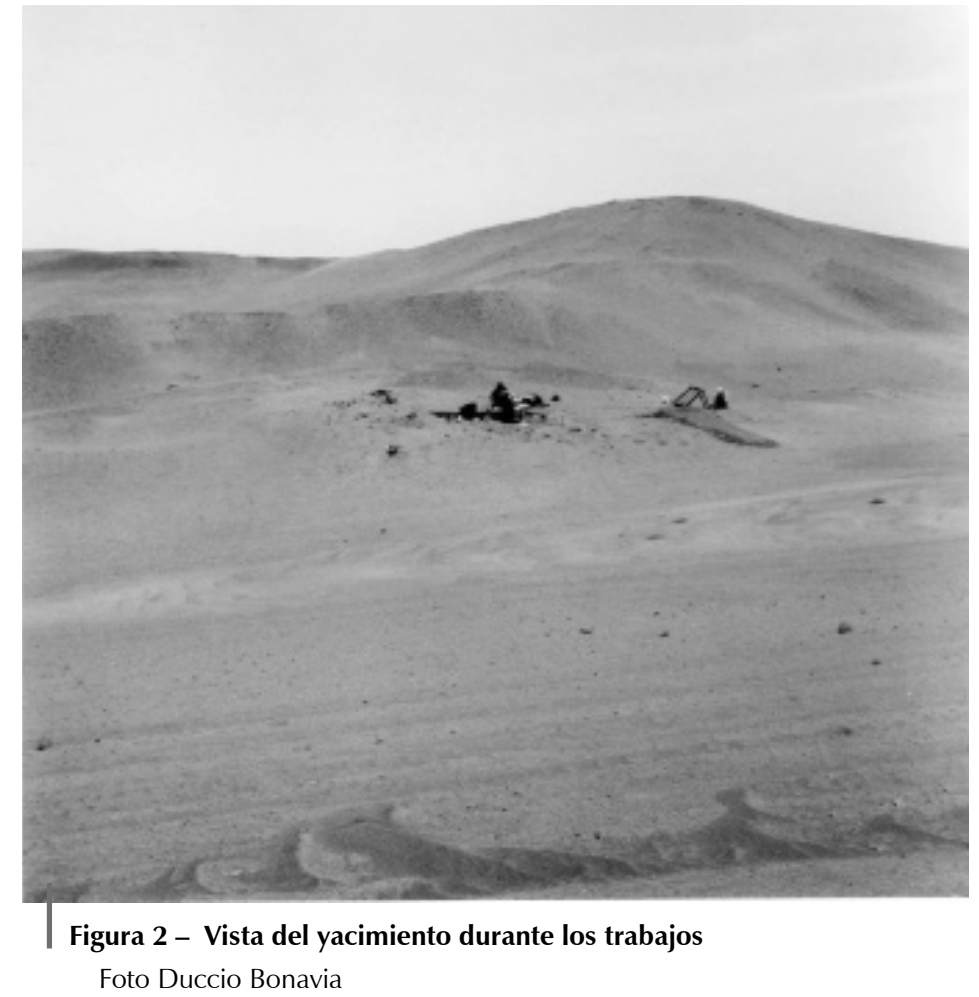




\section{TRABAJOS EFECTUADOS}

Si bien la excavación del sitio no era parte de los planes del Proyecto Arqueológico Huarmey, en vista de que estaba en su estado original y era muy pequeño, decidimos investigarlo. Los trabajos se llevaron a cabo los días 23 y 24 de diciembre de 1976 con el personal y el equipo con el que se estaban terminando las investigaciones en Los Gavilanes. Dado que se disponía de poco tiempo, vimos que hubiera sido imposible excavar todo el yacimiento. Por eso se delimitó un área de $3 \mathrm{~m}$ por 2,5 m ubicada en la parte central del sitio. Se escogió dicha zona ya que pudimos constatar, por pequeños cateos que hicimos en el resto, que el estrato de ocupación en los alrededores era muy delgado. Notamos inmediatamente que este estaba compuesto fundamentalmente por basura, la cual fue cubierta por una capa fina de arena. Evidentemente dado el continuo transporte eólico que se produce en este pasaje natural, no existe la posibilidad de grandes acumulaciones de arena. Esa es la explicación de este tenue estrato que cubría el sitio.

En vista de que la basura se encontraba mezclada con arena, su consistencia era blanda de modo que el trabajo se efectuó simplemente barriendo con cuidado la zona que habíamos delimitado. Durante la excavación se hizo evidente que había solo un estrato, correspondiente a una ocupación única. La roca madre se encuentra en dicha localidad a una profundidad que oscila entre los $30 \mathrm{~cm}$ y los $50 \mathrm{~cm}$. Por encima de ella hay una capa de arena limpia de aproximadamente $13 \mathrm{~cm}$ de espesor. Ella es muy regular y solidificada por la sal, de modo que es imposible confundirla con el estrato que está encima, y que está compuesto por la basura arqueológica que llega hasta la superficie, y — como se ha visto- está solamente recubierta por una capa delgada de arena eólica. Es así que el estrato arqueológico tiene un espesor que oscila entre $17 \mathrm{~cm}$ y $37 \mathrm{~cm}$, según el lugar. Pero, insistimos, se trata de una capa no solidificada donde hay mucha arena mezclada con la basura.

En estos desechos se encontraron casi exclusivamente restos de comida, si se excluyen algunos hilos, sogas, fragmentos de tejidos y un collar. La característica más saltante del sitio es la falta de artefactos, ya que tan solo se pudo encontrar una lasca y unos pocos fragmentos de cerámica. Se recuperaron también coprolitos humanos y animales.

En el centro de la zona excavada que además, como se ha dicho, lo es también del yacimiento, encontramos un hogar grande abierto $y$, a un costado hacia el norte, otro más pequeño. Los restos culturales estaban densamente acumulados alrededor del fogón grande, siendo progresivamente más escasos hacia la periferia. Es alrededor de éste que hallamos los coprolitos humanos. Los fragmentos de cerámica estaban diseminados en la zona excavada.

Dada la pequeñez del yacimiento, la cantidad de restos hallados es considerable y, si se exceptúa algunos que estaban cerca de la superficie y que por eso han sido afectados por la humedad ambiental, todo el resto está en muy buen estado de conservación. 
Encontramos una gran cantidad de grama salada (Distichlis spicata) que sin duda fue utilizada como combustible para los fogones. Pero al mismo tiempo se quemó otra maleza, que estaba muy carbonizada y que ha sido difícil de identificar. Creemos que se trata de lo que comúnmente se conoce como carrizo o carricillo y que probablemente es Phragmites communis (vide Towle, 1961: 19; Hortus S.A. et al., 1973: 58-59). Según Yacovleff \& Herrera (1934: 263) se le conoce también como caña hueca. Se encontró asimismo una considerable cantidad de corontas de maíz, algunas de las cuales estaban carbonizadas. Al sur del fogón central se halló una concentración de excrementos de camélido.

Durante la excavación se vio que los restos vegetales predominaban sobre los de animales. Entre estos últimos hubo un craneo entero de piquero (Sula sp.). Al mismo tiempo, entre los residuos marinos fue claro el predominio de Mytilidae, mientras que entre los vegetales fue evidente un uso importante de maíz y de yuca.

En el hogar encontramos residuos de yuca y camote asados. Hay evidencia que también se asó maíz, pues entre las cenizas hallamos algunos granos quemados. Hubo asimismo semillas completas de fréjoles, pallares y pallares de los gentiles, pero sobre todo una considerable cantidad de cáscaras de los mismos, una buena cantidad de ají y unas pocas cabezas de anchoveta (Engraulidae). Al costado del fogón, dimos con una vaina completa de Canavalia plagiosperma, vulgarmente conocida como «pallar de los gentiles», con todas sus semillas.

El fogón medía aproximadamente $40 \mathrm{~cm}$ por $40 \mathrm{~cm}$ y quedaban pocos fragmentos de carbón. Hubo más bien pequeños restos quemados, que al parecer fueron de material que ardió rápidamente y que dejó solo cenizas, como es el caso del carrizo y sobre todo de la grama salada. El espesor de los restos de este fogón fue tan solo de $10 \mathrm{~cm}$, lo que indica una ocupación temporal. Además el hogar no fue delimitado y entre las cenizas solo encontramos una piedra pequeña quemada. No cabe duda que se cocinó sobre las cenizas. Es posible que una vez que se haya comido el maíz, se haya usado algunas de las corontas como combustible, pues se hallaron algunas de ellas carbonizadas. Aunque esto puede significar también que se expuso las mazorcas al fuego para lograr granos reventados o tostados, lo cual es lo más probable. El fogón menor tenía las mismas características del mayor, pero allí casi no hubo restos de alimentos; solo algunas cáscaras chamuscadas de yuca.

Según los trabajadores que nos ayudaron en la excavación, las hojas del carrizo pudieron haber sido utilizadas también para alimentar al o los animales que dejaron los excrementos y las cañas quizá para hacer un cobertizo provisorio para protegerse del sol y cuyos restos o fueron quemados o abandonados en la superficie y han sido arrastrados por el viento.

En los alrededores inmediatos del sitio no hay ningún otro resto arqueológico.

\section{CRONOLOGÍA RELATIVA}

La única secuencia cronológica completa para el valle de Huarmey, basada fundamentalmente en la cerámica de superficie, es la de Tabío (1977). Pero en 
ella no se explica con detalles la clasificación alfarera. En la medida que Bonavia ha colaborado con el autor consideramos, además, que hay muchos tipos que no han sido incluidos. De modo que nos basaremos fundamentalmente en la larga experiencia que tiene Bonavia de este valle, en las observaciones de la cerámica abandonada por los huaqueros en los cementerios y en algunas colecciones privadas que hemos podido revisar.

En términos generales consideramos que los fragmentos de alfarería encontrados en asociación con los demás materiales de este sitio tienen las características de la cerámica utilitaria del Horizonte Medio. Además, el único resto decorado con incisiones gruesas en la parte externa del borde (fig. 3) y la forma del mismo (fig. 4A) corresponden a la cerámica con círculos impresos que aparece en el Horizonte Medio 3 y va asociada a diferentes manifestaciones de cerámica impresa.

Los arqueólogos japoneses han publicado un fragmento de cerámica correspondiente al borde y parte del cuerpo de un recipiente que es muy parecido al nuestro; la diferencia es que las incisiones son más pequeñas. Muestra, además, una serie de elementos decorativos aplicados sobre el cuerpo, de los que nosotros no tenemos ninguna evidencia (Ishida et al., 1960: 201, Fig. 7). Proviene del sitio que ellos han denominado Maca Hualaca y que en nuestro registro corresponde a PV35-73 y se conoce con el nombre de Macabalaca (Bonavia, 1982: 437 438). Por las exploraciones que se han hecho, la cerámica encontrada en dicho yacimiento corresponde al Horizonte Medio.

En 1989 Bonavia y Ramiro Matos tuvieron la oportunidad de ver los restos de una tumba recién excavada por huaqueros en el cementerio El Castillo (PV3579; Bonavia, 1982: 439) y se pudieron recuperar dos vasijas enteras que, por el testimonio de un vecino, provenían de dicha tumba (fig. 5). Creemos que son contemporáneas con la cerámica que hemos encontrado en nuestro sitio. El contexto de los restos abandonados por los excavadores clandestinos corresponde al Horizonte Medio 3.

Tabío (1977) en su libro no ha incluido los mapas detallados de la localización de sus sitios y desafortunadamente las notas de campo de Bonavia y buena parte de las de Tabío le fueron entregadas a Donald Thompson quien inició sus trabajos

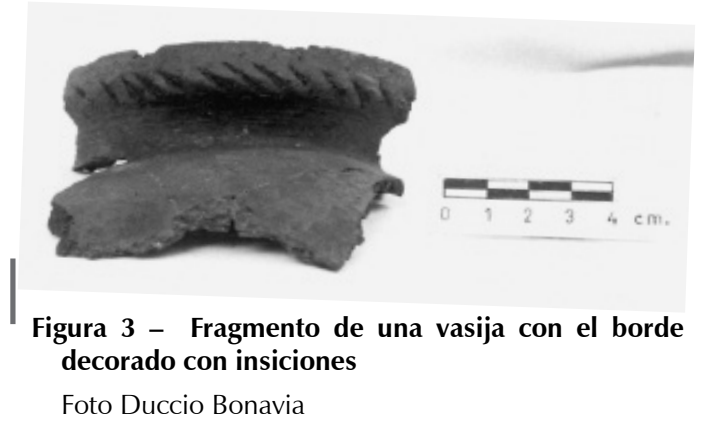

Foto Duccio Bonavia

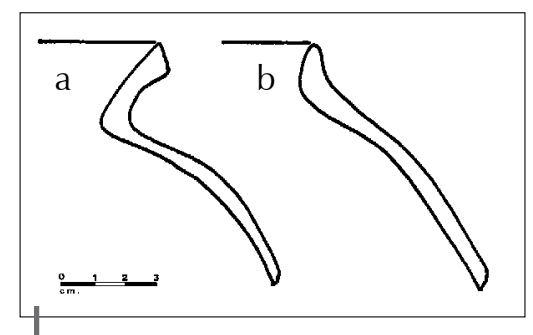

Figura 4 - a: Dibujo del perfil del borde de la vasija ilustrada en la fig. 3; b: Dibujo del perfil del borde de un fragmento de una vasija Dibujo Duccio Bonavia 


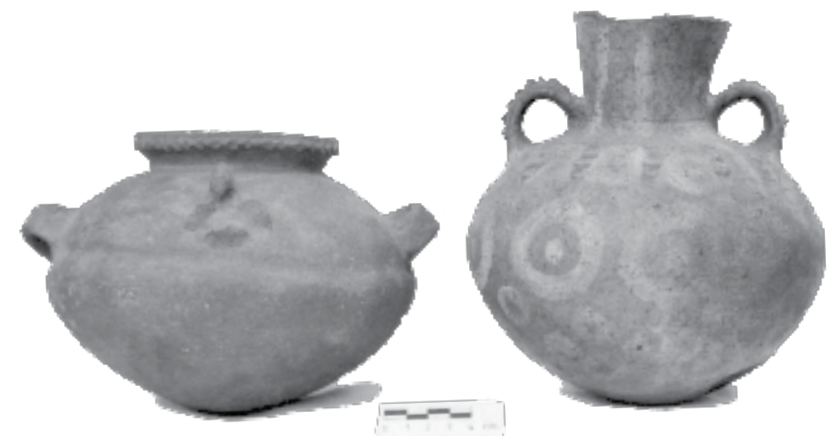

Figura 5 - Vasijas provenientes del cementerio El Castillo Foto Duccio Bonavia

en el valle en 1959, aunque nunca publicó sus resultados, salvo un pequeño artículo muy general (Thompson, 1966). Por lo que recuerda Bonavia que trabajó con Tabío (1977: 101), El Castillo al que nosotros nos referimos corresponde al «Sitio H-51, Área del Castillo (31-V-59)» de este. Él lo subdividió a su vez en «4 subáreas» y la tumba huaqueada a la que nos referimos debería estar en lo que Tabío definió como «H-51-A-Cementerio fase Tardía, Horizonte Medio» (Tabío, 1977: 120). La cerámica en cuestión corresponde a lo que él definió como Tipos «Huarmey Incíso» y «Huarmey Incíso Negro» (vide Tabío, 1977: 153).

Consideramos, pues, que PV35-4 se sitúa en el Horizonte Medio 3 de la cronología de Menzel (1968). Es decir ca. entre 800 y 850 años d.C.

\section{MATERIALES}

\section{1. Lítico}

El único elemento lítico encontrado es una lasca secundaria pequeña. Está muy erosionada por la acción eólica e inclusive sus bordes han perdido el filo cortante. El material es andesita, como la que se utilizó para hacer los artefactos de Los Gavilanes. Esta lasca ha estado enterrada junto con el resto de los artefactos y si hubiera sido hecha y utilizada por los individuos que nos han dejado la basura en PV35-4 no hubiese presentado una erosión eólica tan intensa.

Suponemos que ha sido recogida de la superficie de Los Gavilanes y llevada hasta este sitio por razones que desconocemos.

\section{2. Cerámica}

En total se han encontrado 36 fragmentos de cerámica, la mayoría muy erosionados a causa de las sales y en muy mal estado de conservación. Por sus características 
probablemente formaron parte de aproximadamente 8 recipientes diferentes, pero ninguno de ellos está completo. Solo se han podido juntar tres fragmentos de una vasija y dos de otra. En realidad falta la mayor parte de cada uno de estos recipientes. Se trata, en términos generales, de cántaros relativamente grandes.

Estos fragmentos, con una sola excepción, han sido hechos con la misma pasta. Ella se compone de arcilla mezclada con temperante grueso de piedras con aristas agudas, en un porcentaje de $30-40 \%$. Hay uno solo que parece haber sido elaborado con una arcilla de características diferentes y que tiene un temperante muy fino de piedra. La fractura de estos fragmentos de cerámica es aguda y la textura de la pasta es gruesa.

Los recipientes fueron cocidos en atmósfera oxidante que les ha dado una coloración que varía entre un tono bruno rojo (E 34) y un gris muy oscuro (J 10) (Cailleux \& Taylor, s/f). Hay algunos pocos casos de flambé.

Hay solo una pieza, la que está decorada, que ha sido cocida en una atmósfera reductora. En algunos pocos fragmentos se nota un engobe externo. La superficie de los demás no está muy bien alisada. El espesor de las vasijas varía entre $3 \mathrm{~mm}$ y $7 \mathrm{~mm}$. Todos los recipientes han sido utilitarios y muestran huellas de hollín. En algunos fragmentos la capa de éste es gruesa y sugiere un largo uso.

En toda la colección solo hay dos bordes. En un caso se trata de una olla que debió tener forma esférica con, probablemente, asas verticales en el cuerpo. El perfil de este borde se puede ver en la fig. $4 \mathrm{~A}$ y corresponde a una boca que tuvo un diámetro de 10,61 cm. El segundo borde que se puede apreciar en la fig. 4B, más bien corresponde a una vasija cuyo cuerpo fue alargado y ovalado, y cuyo diámetro de boca es imposible de calcular por la pequeñez del fragmento que ha quedado. Parece haber sido un cántaro relativamente grande.

El primero de estos fragmentos (fig. 4A) tiene una decoración en la parte externa del borde, formada por una serie de incisiones anchas, inclinadas, a una distancia de $7 \mathrm{~mm}$ entre una y otra (fig. 3). En ningún fragmento hay huellas de uso de color.

\section{3. Textiles}

En total se han encontrado ocho fragmentos de tejidos, el mayor de los cuales mide $15 \mathrm{~cm}$ por $17 \mathrm{~cm}$. En un caso se trata en realidad de una masa de tejidos desechos y apelotonados que fueron elaborados con la técnica del entrelazado de pares continuos. Consideramos que ella no atañe a la ocupación de PV35-4, sino que fue recogida de la superficie de Los Gavilanes y traída hasta este sitio por alguno de sus ocupantes. Todas las características de este entrelazado corresponden con las que se conocen para los tejidos precerámicos de dicho sitio (vide Bonavia, 1982: 101 et passim).

Los otros siete fragmentos son de tejidos llanos, elaborados con dos técnicas. La mayoría ( 5 ejemplares que representan el $72 \%$ ) con la variante $1 \times 1$ (balanced plain weave de Emery [1980: Fig. 85, 76]) (fig. 6, T208) y la minoría (o sea 2 fragmentos, $28 \%$ ) con la variante $2 \times 2$ (Plain weave with paired warp and weft, Emery [1980: Fig. 89, 77]) (fig. 7, T203). 


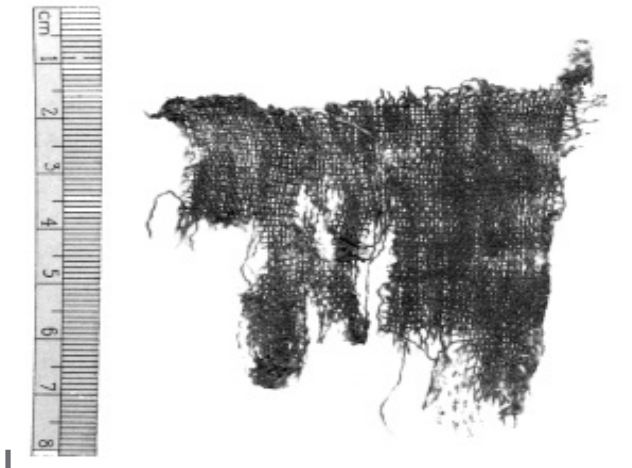

Figura 6 - Fragmento de tejido Ilano (1x1) Foto Duccio Bonavia
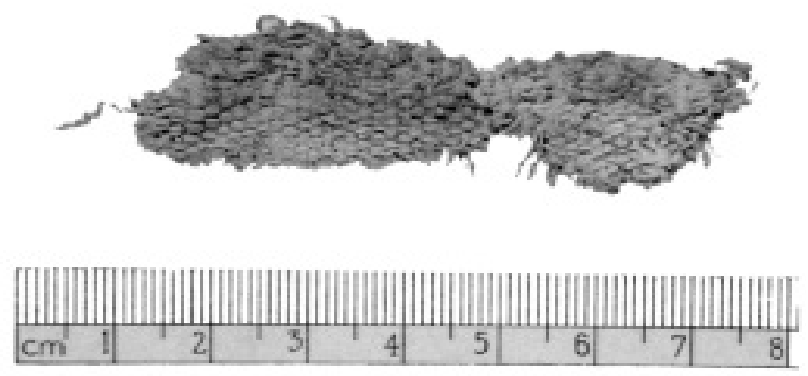

Figura 7 - Fragmento de tejido Ilano (1x1)

Foto Duccio Bonavia

La trama de todos estos tejidos ha sido elaborada con algodón y el diámetro promedio es de 0,5 $\mathrm{mm}$, siendo el máximo de 0,7 $\mathrm{mm}$ y el mínimo de 0,3 $\mathrm{mm}$. El $86 \%$ de los hilos está torcido en S y el 14 \% en Z. El ángulo de torsión del hilado en promedio es de $32^{\circ}$, siendo el ángulo máximo de $48^{\circ}$ y el mínimo de $20^{\circ}$. El promedio del número de torsiones en un retorcido por unidad (correspondiente a $1 \mathrm{~cm}$ ) es de 9, siendo el máximo 19 y el mínimo 4 .

El color predominante de la fibra es el marrón (71 \%) y le sigue el blanco (29 \%). La tensión de los hilos de la trama es media en el 28 \% y fuerte en el $71 \%$ de los casos (para estas mediciones hemos seguido el método de Emery, 1980: 11 12). La cuenta promedio por $\mathrm{cm}$ es de 17 , siendo la cantidad máxima de 28 y la mínima de 8.

Las características de las urdimbres en términos generales son iguales a las de las tramas, con la diferencia del ángulo de torsión del hilado que en promedio mide $30^{\circ}$, aunque las medidas máximas y mínimas se mantienen las mismas que en la trama, mientras que la tensión varía ligeramente. En efecto hay un 42 \% con tensión media y un 57 \% con tensión fuerte.

Hay algunas peculiaridades de estos tejidos que merece la pena señalar. Es el caso del ejemplar T205, que es un tejido llano 1x1 en el que hay un tratamiento interesante en el borde de trama: se ha utilizado un hilo igual al de las tramas y urdimbres del tejido, alrededor del cual dan vuelta las urdimbres. Aparentemente se sujeta con el hilo adicional amarrado al costado (ver fig. 8). Además, este tejido tuvo una estructura suplementaria. Se ha añadido al costado un hilo más grueso que pudo haber servido para amarrar la tela a algo. Este tiene un espesor de 1,2 mm, y está compuesto por cuatro elementos, torcidos en $\mathrm{S}$ y retorcidos en $\mathrm{Z}$. Va anudado al costado y el nudo es la base del amarre que se ha hecho utilizando dos hilos de la trama. Pero la parte superior es incompleta y posiblemente el amarre fue más completo (ver fig. 9).

Luego tenemos el ejemplar T209 que fue un tejido teñido en un tono azul. El tinte no ha penetrado bien, de modo que el blanco del algodón se ve y le otorga un color 


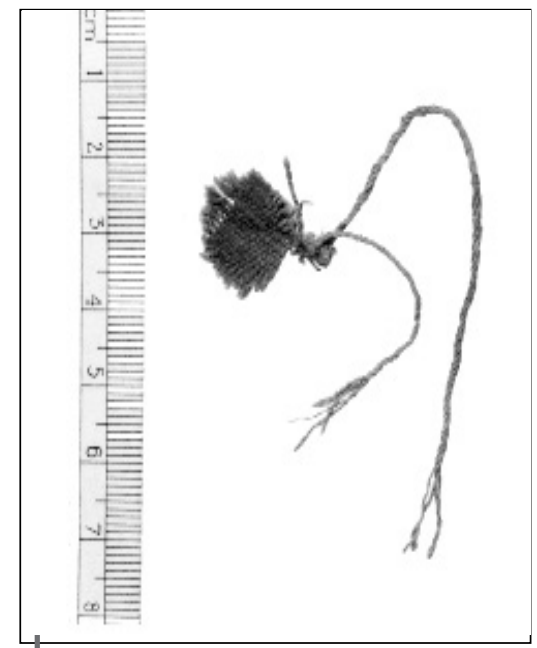

Figura 8 - Fragmento de tejido llano 1x1 con tratamiento especial del borde de trama. (Ver fig. 9)

Foto Duccio Bonavia

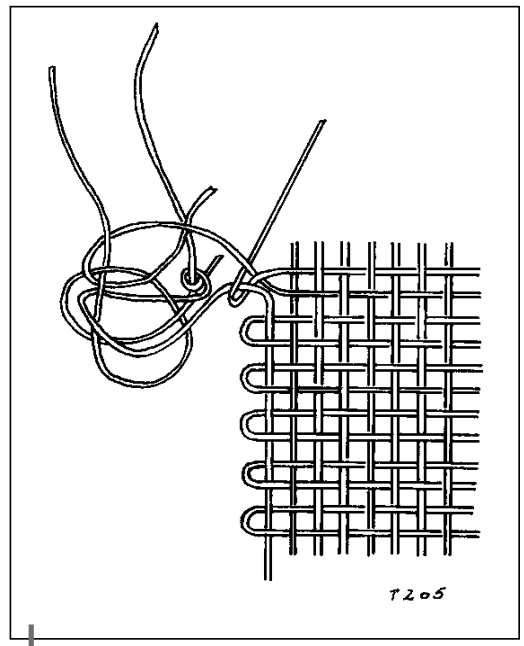

Figura 9 - Dibujo del tejido ilustrado en la fig. 8 y que muestra el detalle de la estructura suplementaria

Dibujo Duccio Bonavia

claro muy especial. Finalmente, debemos mencionar el ejemplar T210 (fig. 10) que es básicamente un tejido llano $2 \times 2$, pero que en algunos sectores se convierte a $3 \times 4 \times 4 \times 2$ para seguir luego en $2 \times 2$. En la parte superior del fragmento de este tejido que nos ha quedado, se ha creado una banda decorativa, introduciendo entre las urdimbres un elemento adicional. Esto se repite seis veces. Solo en un lugar se ha añadido una trama suplementaria, que pasa entre las tramas normales cuatro veces y se sujeta tal como se ve en el dibujo (fig. 11). Además, en la parte inferior del tejido, se nota que este fue doblado, y para que se mantuviera así se le ha asegurado en dos puntos con hilos gruesos (1,1 $\mathrm{mm}$ de espesor) torcidos en $Z$, en la forma que se ve en la parte inferior izquierda del dibujo.

\section{4. Sogas, soguillas e hilos}

Entre los restos excavados se encuentran una buena cantidad de sogas, soguillas, hilos y restos de algodón cuya descripción nos parece importante. En primer lugar hay doce fragmentos de sogas y soguillas de fibra vegetal que no hemos podido identificar, pero que en algunos casos creemos que sea Fourcroya sp. (conocida vulgarmente con muchos nombres [vide Soukup, s/f [1987]: 184]; en la zona de Huarmey como cabuya) y en otros alguna variedad de junco (Scirpus sp.?). Se trata en términos generales de fragmentos pequeños y solo uno de ellos mide $20 \mathrm{~cm}$ de largo. En la fig. 12 se puede ver en la parte superior una soguilla de junco, luego otra de fibra vegetal y dos más.

En todos estos ejemplares se han empleado dos elementos, de los cuales un $67 \%$ se torció en $Z$ y retorció en S y un 33 \% fue torcido en S y retorcido en Z. Cuatro 
Duccio Bonavia et al.

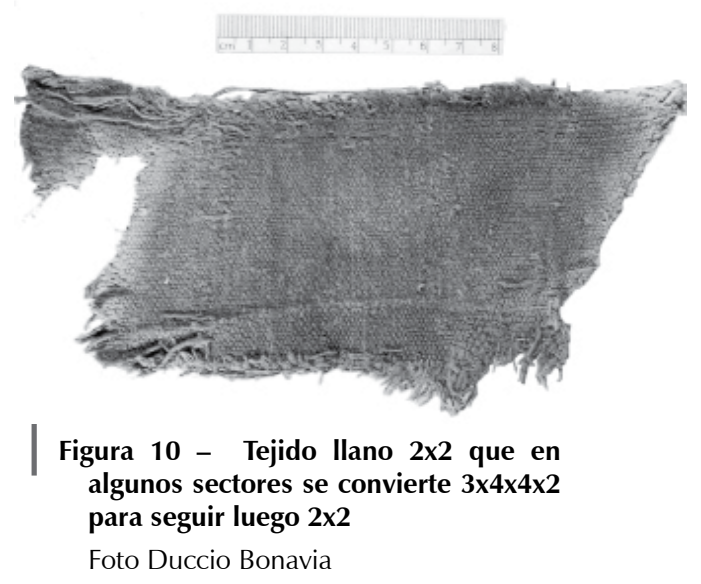

Foto Duccio Bonavia

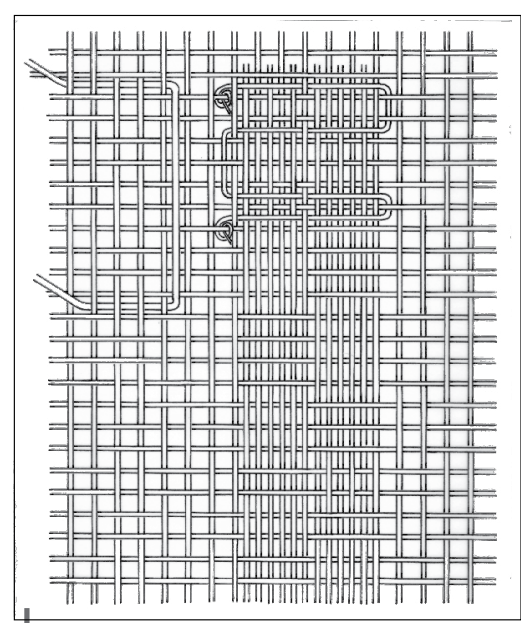

Figura 11 - Dibujo que muestra las características del tejido de la fig. 10

Dibujo Duccio Bonavia

ejemplares muestran la unión de dos soguillas por medio de un nudo simple. El espesor de estos especímenes varía entre $0,6 \mathrm{~mm}$ y $5 \mathrm{~mm}$, siendo el promedio $1,6 \mathrm{~mm}$.

Entre estos especímenes consideramos interesante señalar un fragmento de junco (FB67; de un solo elemento), que a ambos extremos lleva amarrados otros juncos de la manera que se ve en la fig. 13. El nudo de la derecha corresponde a lo que Emery (1980: Fig. 31, 37) Ilama vertical granny knot.

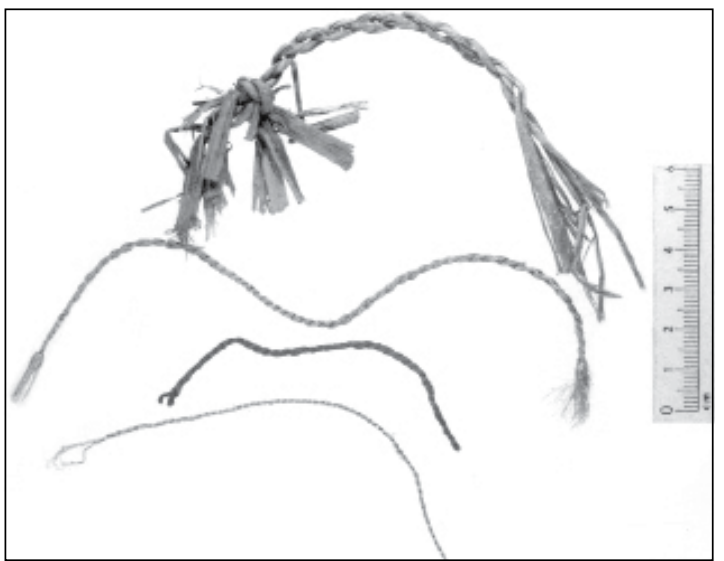

Figura 12 - En la parte superior se muestra una soguilla de junco y en la inferior tres soguillas de fibra vegetal no determinada

Foto Duccio Bonavia

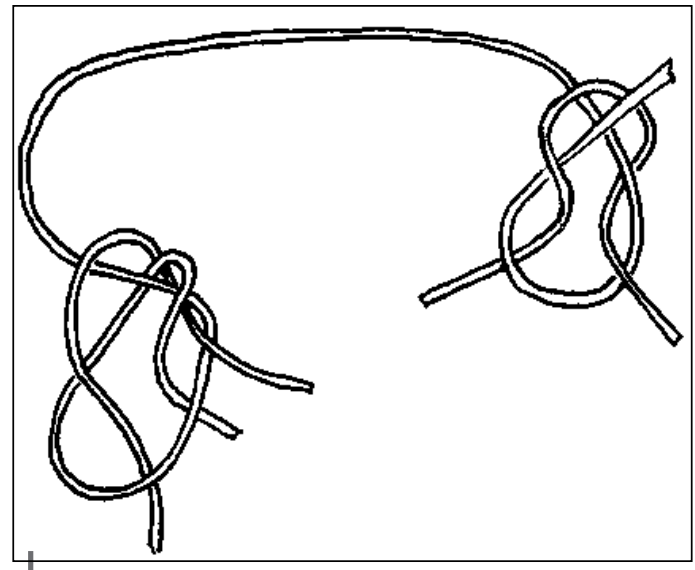

Figura 13 - Dibujo de un fragmento de junco que a ambos extremos Ileva amarrados otros juncos Dibujo Duccio Bonavia 
Hay, además, algunos especímenes que nos parece importante describir con cierto detalle. Es el caso de un junco grueso (FB63) de $7 \mathrm{~mm}$ de ancho que fue doblado y atado con otro más delgado de 3,7 $\mathrm{mm}$ de espesor para que no pudiera abrirse. Para que este último no se desatara, se le aseguró con un tercer junco delgado (ver fig. 14). Otro es el de una soga de fibra vegetal no identificada, gruesa (8 $\mathrm{mm}$ de espesor) y compuesta por 2 elementos torcidos en $\mathrm{S}$ y retorcidos en $\mathrm{Z}$, que ha sido unida con otra más delgada (de $6 \mathrm{~mm}$ de espesor) y formada por dos elementos torcidos en $\mathrm{Z}$ y retorcidos en $\mathrm{S}$ por medio de un nudo simple, del tipo que Emery (1980: Fig. 19, 34) define simple knot: overhand.

Hay también cuatro ejemplares muy interesantes y que no sabemos si fueron soguillas o hilos aunque lo segundo es lo más probable. Son excepcionalmente largos y bien conservados: miden respectivamente $40 \mathrm{~cm}, 40 \mathrm{~cm}, 76 \mathrm{~cm}$ y $82 \mathrm{~cm}$. Están compuestos por dos elementos torcidos en $\mathrm{Z}$ y retorcidos en $\mathrm{S}$, con torsión media y retorcido fuerte. Las fibras son de lana de alpaca; su análisis ha sido efectuado en el Laboratorio del Programa de Ovinos y Camélidos Americanos de la Facultad de Zootecnia de la Universidad Nacional Agraria de La Molina (Lima). (La fig.15 muestra tres de estos hilos.)

En total se han analizado ocho muestras; dos de ellas corresponden a la primera soguilla o hilo (O47, 1a y 1b), tres a la segunda (O47 2a, 2b, 2c), una a la tercera $(\mathrm{O} 47,3)$ y dos a la cuarta $(\mathrm{O} 47,4 \mathrm{a}$ y $4 \mathrm{~b})$. Las muestras han sido medidas por
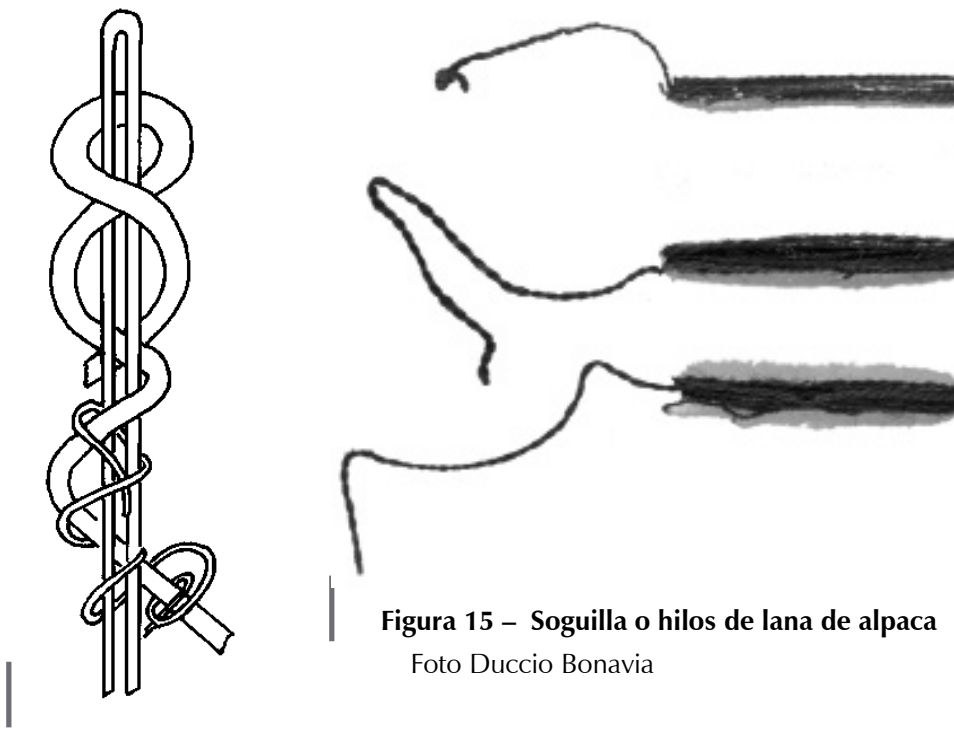

Figura 14 - Dibujo de un junco grueso que fue doblado y atado con otro más delgado para que no pudiera abrirse. Para que el último no se desatara, se le agregó un tercer junco delgado Dibujo Duccio Bonavia 
microproyección de 500X y de acuerdo a las especificaciones de ASTM D2252-7613.

Los resultados del análisis se muestran en la Tabla 1, en la que se consignan el código de la muestra, la identificación de la fibra, el diámetro promedio $(\bar{x})$ en micras $(\mu \mathrm{m})$, la Desviación Estándar, el Coeficiente de Variación y el Intervalo de Diámetro de cada muestra. En función de estos valores se ha aplicado la tabla 2 que permite deducir las siguientes conclusiones.

En primer lugar todas las muestras son de fibra de alpaca (Lama pacos). El diámetro promedio medido en micras $(\mu \mathrm{m}=1$ milésima de un milímetro) oscila entre $25,53 \mu \mathrm{m}$ y $33,08 \mu \mathrm{m}$.

Los diámetros varían entre $11,25 \mu \mathrm{m}$ que corresponden a la fibra de mayor finura y $71,25 \mu \mathrm{m}$ a la de mayor grosor.

Tabla 1 - Análisis de las fibras de Camelidae

\begin{tabular}{|c|c|c|c|c|c|c|}
\hline $\mathbf{N}^{\circ}$ & Muestra & Fibra & $\begin{array}{c}\text { Diámetro (micras) } \\
\boldsymbol{\mu m} \overline{\mathbf{x}}\end{array}$ & $\mathbf{D . S .}$ & $\mathbf{C . V . \%}$ & Intervalo-Diámetro \\
\hline 1 & $0471 \mathrm{a}$ & Alpaca & 27,47 & 8,22 & 29,94 & $13,75-53,75$ \\
\hline 2 & $047 \mathrm{1b}$ & Alpaca & 25,53 & 8,31 & 33,88 & $11,25-56,25$ \\
\hline 3 & $0472 \mathrm{a}$ & Alpaca & 26,11 & 7,74 & 29,64 & $11,25-58,75$ \\
\hline 4 & $0472 \mathrm{~b}$ & Alpaca & 33,05 & 10,02 & 30,33 & $13,75-68,75$ \\
\hline 5 & $0472 \mathrm{c}$ & Alpaca & 28,54 & 7,59 & 26,59 & $13,75-68,75$ \\
\hline 6 & 0473 & Alpaca & 29,65 & 6,15 & 20,76 & $16,25-48,75$ \\
\hline 7 & $0474 \mathrm{a}$ & Alpaca & 26,43 & 6,74 & 25,49 & $11,25-58,75$ \\
\hline 8 & $0474 \mathrm{~b}$ & Alpaca & 33,08 & 9,91 & 29,95 & $21,25-71,25$ \\
\hline$\mu \mathrm{m}$ x: promedio; DS.: desviación estándar; C.V.: coeficiente de variación \\
\hline
\end{tabular}

Por su diámetro, el $76 \%$ de estas muestras se ubica entre $25,00 \mu \mathrm{m}$ y $29,99 \mu \mathrm{m}$ que, según la Tabla 2, se ajusta a la clasificación AA considerada como Media y $\mathrm{HZ}$ como Media gruesa y $24 \%$ entre $30,00 \mu \mathrm{m}$ y $35,99 \mu \mathrm{m}$ que se ajusta a la clasificación AG que corresponde a Muy gruesa y variable.

La variabilidad del diámetro de las fibras medidas se cataloga como mediana y alta. En los rebaños actuales de alpacas, existen vellones que superan estos promedios, tanto en diámetro como en variabilidad.

También se ha encontrado una cantidad importante de hilo de algodón blanco, cuidadosamente doblado y amarrado como se ve en la fig. 16. Hay dos tipos de

13 American Society for testing materials (U.S.A.), ITINTEC Perú, Especificaciones de finura de tipo de alpaca, 438-439. 
Tabla 2 - Clasificación de las fibras de alpaca

\begin{tabular}{|c|c|c|}
\hline Símbolos & Significado & Límites de diámetro $(\boldsymbol{\mu} \mathbf{m})$ \\
\hline $\mathrm{T}$ & Extra fina & $<22,00$ \\
\hline $\mathrm{XT}$ & fina & 22,00 a 24,99 \\
\hline $\mathrm{X}$ & fina & 22,00 a 24,99 \\
\hline $\mathrm{AA}$ & Media & 24,00 a 26,00 \\
\hline HZ & Media gruesa & 26,00 a 29.00 \\
\hline AG & Muy gruesa y variable & 30,00 a 35,99 \\
\hline SK & Bragas & $>30,00$ \\
\hline LP & Fibras cortas & $>30,00$ \\
\hline
\end{tabular}

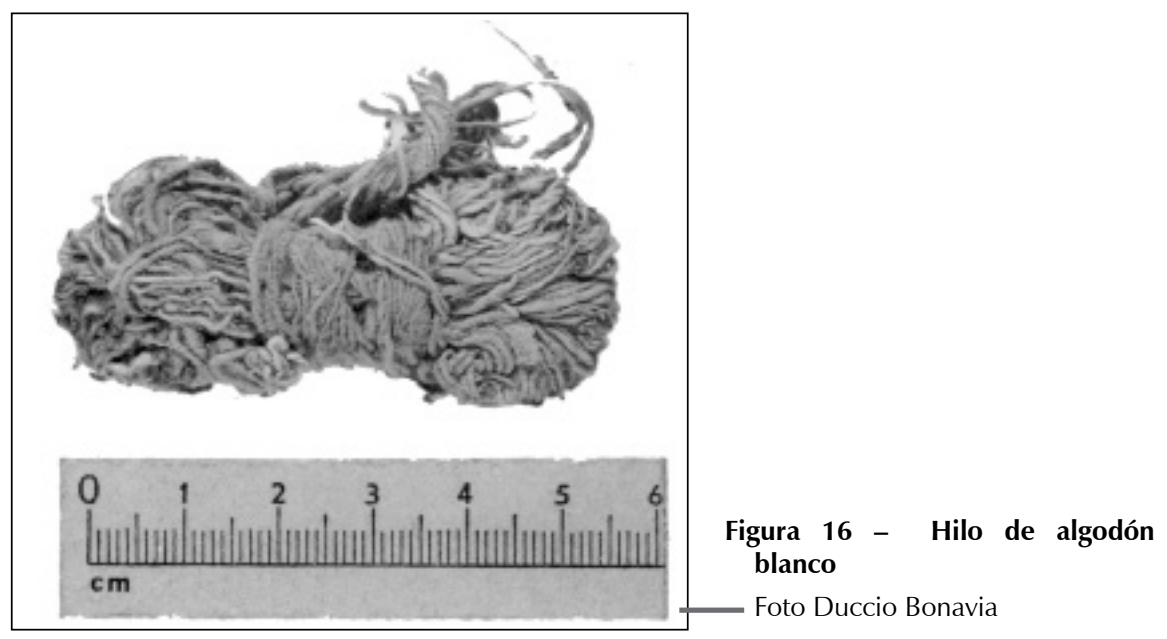

hilos, uno torcido en $\mathrm{S}$, con un espesor de $0,7 \mathrm{~mm}$ y el otro torcido en $\mathrm{Z}$ con 1,1 $\mathrm{mm}$ de espesor.

Finalmente hay una soga de fibra vegetal, de tres elementos, cada una con composición diferente. Uno de un solo elemento torcido en $S$, otro de 2 elementos torcidos en $\mathrm{S}$ y retorcidos en $\mathrm{Z}$ y un tercero compuesto por 3 elementos torcidos en $Z$ y retorcidos en $Z$. Estos tres elementos principales han sido a su vez unidos y retorcidos en $S$, formándose de esta manera una soga de $3 \mathrm{~mm}$ de espesor. En un punto esta ha sido amarrada por tres soguillas, formadas cada una por 2 elementos torcidos en $Z$ y retorcidos en $Z$, con un espesor de 1,3 mm. Las ataduras, que son independientes, han sido hechas con nudo «cabeza de alondra», que en la terminología de Emery (1980: Fig. 27, 37) corresponde a cow hitch, or lark's head knot. A partir de este nudo la soga se desdobla y cada elemento constituye 
una unidad independiente. Ella ha sido recubierta por una sustancia dura, color marrón oscuro, que en partes se ha perdido y que parece ser resina vegetal.

Además se ha hallado seis soguillas de algodón blanco y pardo y algunos hilos del mismo material. En lo que a las soguillas se refiere, el 50 \% está compuesto por 2 elementos y el $17 \%$ (que corresponde a un solo ejemplar) de siete. Ellas han sido torcidas en $Z$ y retorcidas en $\mathrm{S}$ en $17 \%$ de casos y el resto (o sea el $83 \%$ ) ha sido torcido en $\mathrm{S}$ y retorcido en $\mathrm{Z}$. El espesor varía entre $0,6 \mathrm{~mm}$ y $2,6 \mathrm{~mm}$, siendo el promedio 1,4 mm. Entre estos materiales hay un elemento que ha sido teñido en azul por sectores.

Finalmente hay dos hilos de algodón, uno torcido en $\mathrm{S}$ y el otro en $\mathrm{Z}$; tienen respectivamente $0,4 \mathrm{~mm}$ y $0,7 \mathrm{~mm}$ de espesor.

\section{5. Varios}

Hay asimismo unas motas de algodón blanco de dos tonos (uno muy blanco y otros más oscuros) y de algodón pardo. Igualmente un pequeño bulto de fibras vegetales, casi seguramente de Fourcroya sp. conocida vulgarmente como maguey.

Entre la basura se encontró también un collar que fue hecho con junco machacado cuyas fibras fueron torcidas en $\mathrm{S}$ y en el que se ha ensartado tres conchas de lapa (Fissurella limbata) aprovechando su orificio natural. Una de ellas está rota. Los dos extremos de la fibra fueron unidos por medio de un nudo simple. La fibra está rota en un punto, pero su largo es de $43 \mathrm{~cm}$, de modo que el collar tuvo un diámetro de poco más de $13 \mathrm{~cm}$ (fig. 17).

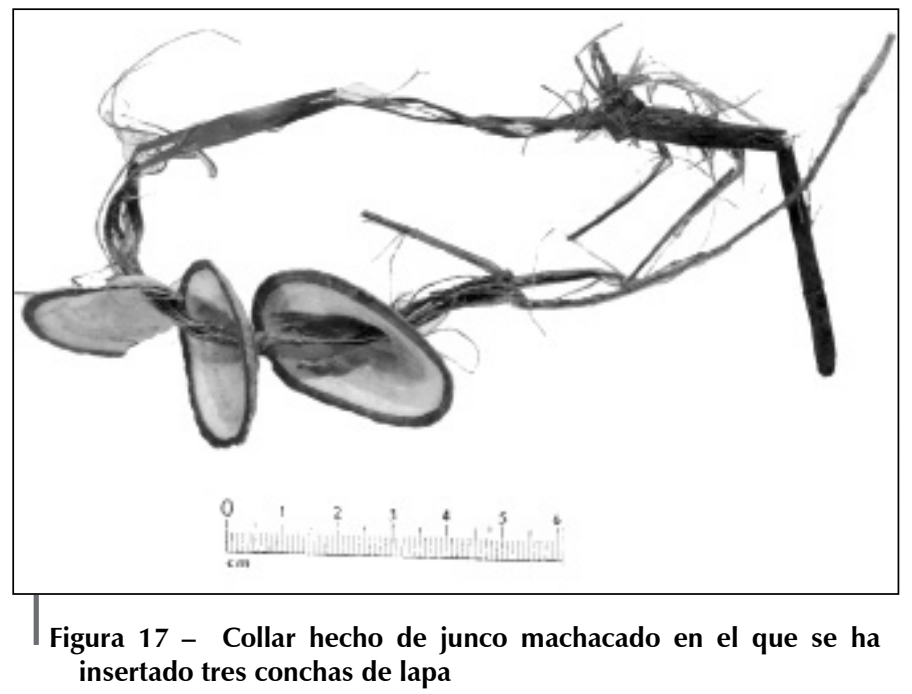

Foto Duccio Bonavia 


\section{RESTOS BOTÁNICOS}

\section{1. Metodología de estudio}

La mayoría de los restos analizados no están carbonizados. Dadas las excelentes condiciones de conservación de estos materiales, para los fines de identificación fue suficiente un análisis macroscópico. Sin embargo se utilizó un microscopio binocular estándar de disección con un poder de ampliación de 7-30X para distinguir la cáscara de la Lagenaria de la de Cucurbita. Debido a la gran cantidad de material que se tuvo que examinar, no se pudo hacer un análisis cuantitativo por categoría taxonómica; en cambio se ha seleccionado cuidadosamente las especies de plantas que tienen una importancia económica y ellas han sido descritas y medidas.

Las identificaciones han sido hechas cotejando los materiales de Huarmey con las colecciones comparativas existentes en el Laboratorio de Etbotánica del Museo de Antropología de la Universidad de Michigan, mientras que algunos especímenes desconocidos han podido ser determinados con la ayuda de la descripción de malezas de la Costa Norperuana que hiciera Sagástegui Alva (1973). Dado que las cañas y los yerbajos son notoriamente difíciles de identificar sin un apropiado material comparativo, este análisis se ha concentrado en aquellas plantas que fueron recolectadas o cultivadas con fines alimenticios o por otros propósitos industriales. La lista de plantas identificadas se puede ver en la Tabla 3 y se nota que ellas son típicas del area costeña. Este conjunto incluye al maíz, a los fréjoles, a los pallares, a los pallares de los gentiles, a las calabazas, a los mates, a los camotes, a los ajíes y al algodón, a lo que hay que añadir algunas plantas silvestres económicamente importantes o plantas «estimuladas» como el algarrobo. A esto hay que agregar las algas.

\section{1. 1. Plantas alimenticias cultivadas}

\section{Annonaceae}

El fruto de la chirimoya (Annona cherimolia) está representado por una sola semilla que mide 16,20 $\mathrm{mm}$ de largo por 8,91 $\mathrm{mm}$ de ancho y 7,18 $\mathrm{mm}$ de grosor (Bonavia et al., 2004: 515, Fig. 3) (fig. 18a).

\section{- Convolvulaceae}

De esta Familia hay seis tubérculos y cinco fragmentos de epidermis de camote (Ipomoea batatas). Los tubérculos han sido identificados por Emma Cerrate de Ferreyra a base de las características macrobotánicas. Si bien es cierto que los tubérculos son difíciles de identificar sin un análisis microscópico de la anatomía de los granos de almidón, hay algunos de este yacimiento que tienen características morfológicas de la superficie tan bien conservadas que ellas pueden ser reconocidas como camote con razonable seguridad (fig. 18b). 
Tabla 3 - Restos botánicos

\begin{tabular}{|l|l|l|}
\hline \multicolumn{1}{|c|}{ Especies } & \multicolumn{1}{c|}{ Familia } & \multicolumn{1}{c|}{ Partes de la planta } \\
\hline Annona cherimolia & Annonaceae & Semilla \\
\hline Canavalia sp. y C. plagiosperma & Fabaceae & $\begin{array}{l}\text { Semillas, cotiledones, cáscara y } \\
\text { una vaina completa }\end{array}$ \\
\hline Capsicum sp. & Solanaceae & $\begin{array}{l}\text { Fruto, fragmento de fruto, } \\
\text { semillas }\end{array}$ \\
\hline Cucurbita sp. & Cucurbitaceae & Fragmentos de cáscara \\
\hline Euphorbia heterophylla & Euphorbiaceae & Semilla, cápsula \\
\hline Gossypium barbadense & Malvaceae & Fibra \\
\hline Ipomoea batatas & Convolvulaceae & $\begin{array}{l}\text { Tubérculos y fragmentos de } \\
\text { epidermis }\end{array}$ \\
\hline Lagenaria siceraria & Cucurbitaceae & Fragmentos de cáscara \\
\hline Manihot esculenta & Euphorbiaceae & Tubérculos, semilla y tallos \\
\hline Phaseolus lunatus & Fabaceae & Semillas, vainas \\
\hline Phaseolus vulgaris & Fabaceae & Semillas, vainas \\
\hline Prosopis pallida & Mimosaceae & $\begin{array}{l}\text { Semillas, vaina, fragmentos de } \\
\text { vaina }\end{array}$ \\
\hline Zea mays & Poaceae & $\begin{array}{l}\text { Corontas, granos, barbas, } \\
\text { fragmentos de panojas, pancas, } \\
\text { un tallo. }\end{array}$ \\
\hline Desconocida & Asteraceae & Cabezuelas y semillas \\
\hline Desconocida & Poaceae & Hoja \\
\hline Tubérculos no identificados & Lessoniaceae & Talos y frondes \\
\hline & & Raíz \\
\hline
\end{tabular}

\section{Cucurbitaceae}

Esta Familia está representada en el sitio por dos géneros: las calabazas (Cucurbita sp.) y los mates (Lagenaria siceraria) (Vide pág. 261). En este caso no hay semillas sino solo veinte fragmentos de cáscara de ambos géneros (fig. 18c).

\section{Euphorbiaceae}

La yuca, Manihot esculenta, ha sido identificada por sus tubérculos, una semilla (fig. 18d) y algunos tallos. Los restos de esta planta representan una gran parte de los especímenes botánicos de este sitio. La única semilla que se ha encontrado, mide 11,45 $\mathrm{mm}$ de largo por 6,93 $\mathrm{mm}$ de ancho y 3,66 $\mathrm{mm}$ de grosor. 


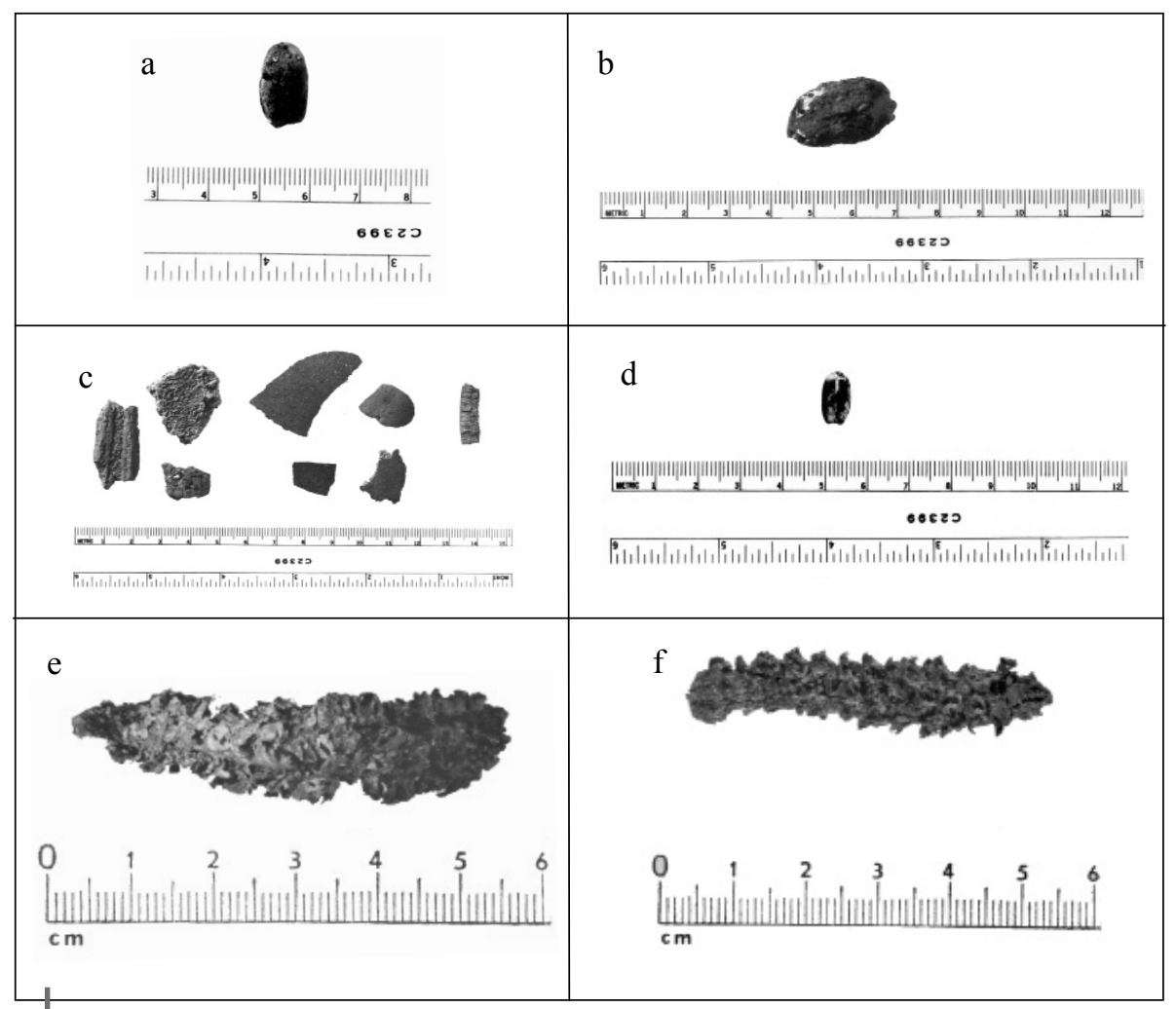

Figura 18 - a: Semilla de chirimoya; b: Tubérculo de camote; c: Fragmento de cáscara de Cucurbitácea; d: Semilla de yuca; e: Coronta de Proto-Confite Morocho; f: Coronta de Proto-Confite Morocho que muestra sus cúpulas

Figuras 18a-18d: Fotos Laura W. Johson-Kelley; Figuras 18e-18f: Fotos Duccio Bonavia

\section{Poaceae}

De esta Familia son comunes las hojas de malezas. Pero lo más importante son los restos de maíz.

- Maíz (Zea mays)

En total se han podido recuperar 98 corontas enteras de las cuales 35 tienen granos. Además se recuperaron 140 corontas fragmentadas en buen estado, 18 de las cuales conservan granos. Hay 44 fragmentos de corontas que están en muy mal estado de conservación y 11 que están carbonizados. Además se hallaron 37 granos de los cuales 3 están carbonizados. Hay también barbas, fragmentos de panojas, 2 pancas y un tallo con sus raíces.

Las corontas intactas tienen una longitud que varía entre 28 y $122 \mathrm{~mm}$ con una mayor concentración en las longitudes menores de $70 \mathrm{~mm}$, según se puede apreciar en la Tabla 4. Es interesante observar que predominan las corontas de 
Tabla 4 - Distribución de las longitudes de las corontas de maíz en mm

\begin{tabular}{|l|c|c|c|c|}
\hline Grupos & 28 a 50 & 50 a 70 & 70 a 90 & más de 90 \\
\hline Cantidad & 34 & 37 & 24 & 4 \\
\hline
\end{tabular}

menor longitud sobre las pocas que son más largas. Trataremos de explicar la coexistencia de ambas en la discusión final.

En un caso las corontas muestran espiguillas terminales masculinas, pero hay otro que es interesante y es el de una coronta en la que se alternan hileras de granos normales con una hilera de granos medio abortados y en la que aparecen sustituidos por estructuras que se asemejan a espiguillas masculinas. En esta coronta las cúpulas son expuestas, de color púrpura, con 8 granos por hilera, gluma externa córnea con un ángulo de 30 a 35 grados con el eje de la coronta.

El número de hileras de granos en la muestra se da en la distribución de corontas completas y fragmentos examinados, como se ve en la Tabla 5. El análisis de esta distribución indica la gran predominancia del bajo número de hileras de granos, lo que indica una gran penetración en esta muestra de mazorcas de la raza ProtoConfite Morocho, aunque la evolución hacia 10 hileras de granos que iguala a las de 8 , indica un avance por selección para más número de granos por mazorca sin cambiar sus características. Esta sería una primera forma de avance en la selección. El incremento del número de hileras va acompañado por una fasciación mayormente ligera, ya que el número de hileras raramente pasa de 10 en esta población.

Tabla 5 - Distribución del número de hileras de granos en las corontas de maíz

\begin{tabular}{|l|c|c|c|c|c|}
\hline Número de hileras & 8 & 10 & 12 & 14 & 16 \\
\hline Cantidad & 77 & 75 & 14 & 2 & 1 \\
\hline
\end{tabular}

En ella se mantiene una presencia de Proto-Confite Morocho (6 corontas, fig. 18e. En el lado izquierdo se pueden observar sus cúpulas; fig.18f), Proto-Kculli (fig. 19a) con 6 corontas y Confite Chavinenese con 5 corontas completas y una fragmentada (fig.19b, el primer ejemplar de la izquierda es típico) sobre el total de 238. Entre estas hay algunas híbridas Proto-Confite Morocho/Proto-Kculli (fig. 19c). Pero lo que es sumamente importante señalar, es que 50 corontas sobre las 98 completas, es decir más del $50 \%$, muestran glumas de color púrpura aún en esta época. Esta coloración basada en la serie $\mathrm{A}, \mathrm{B}, \mathrm{Pl}$ y $\mathrm{R}$ de genes en cuatro cromosomas diferentes, es un indicador poderoso del origen altoandino de las plantas de las que se cosecharon las mazorcas (lege Greenblat, 1968).

En las muestras hay también evidencias de razas más avanzadas, como un incipiente Proto-Alazan (5 corontas completas y una incompleta, fig. 19d), ProtoPagaladroga (7 ejemplares completos. fig. 19e con algunos granos y fig. 19f en la que la coronta de la parte superior es típica), Huayleño (1 coronta) e incluso Proto-Rabo de Zorro (2 corontas incompletas, fig. 20a), esta última siendo una 


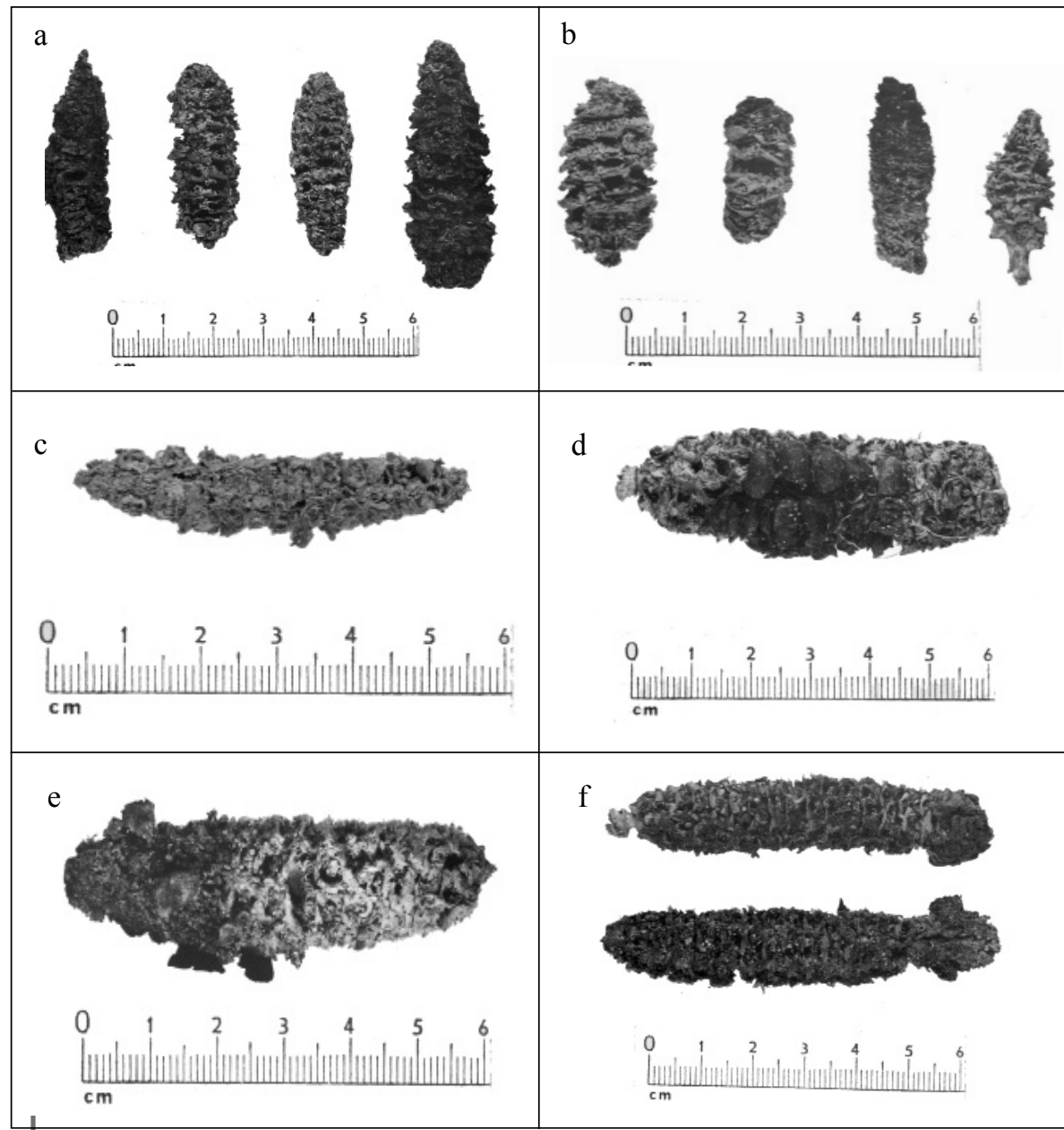

Figura 19 - a: Coronta de Proto-Kculli; b: Coronta de Confite Chavinense; c: Híbrido de Proto-Confite Morocho con Proto-Kculli; d: Coronta de un incipiente ProtoAlazán; e: Coronta de Proto-Pagaladroga; f: Corontas de Proto-Pagaladroga. La superior es típica

Figuras 19a-18f: Fotos Duccio Bonavia

raza cuyo desarrollo posterior parece centrarse en el valle del Marañón, aunque hay evidencia de su existencia en la costa en épocas más recientes, por ejemplo en los tiempos mochicas (vide Grobman et al., 1961: Figs. 31, 32 y 33: 101 103). Hay una coronta que parece demostrar la presencia de Proto-Chullpi o de una de sus razas emparentadas cruzada con Proto-Pagaladroga (fig. 20b).

Se ha recuperado también una coronta primitiva ramificada con características de tassel seed. El raquis central es relativamente grueso, tiene granos bien desarrollados de pericarpio rojo que también se encuentra en dos ramas axilares o laterales. Sus cúpulas son muy pilosas, expuestas, de color púrpura, de 6 mm 


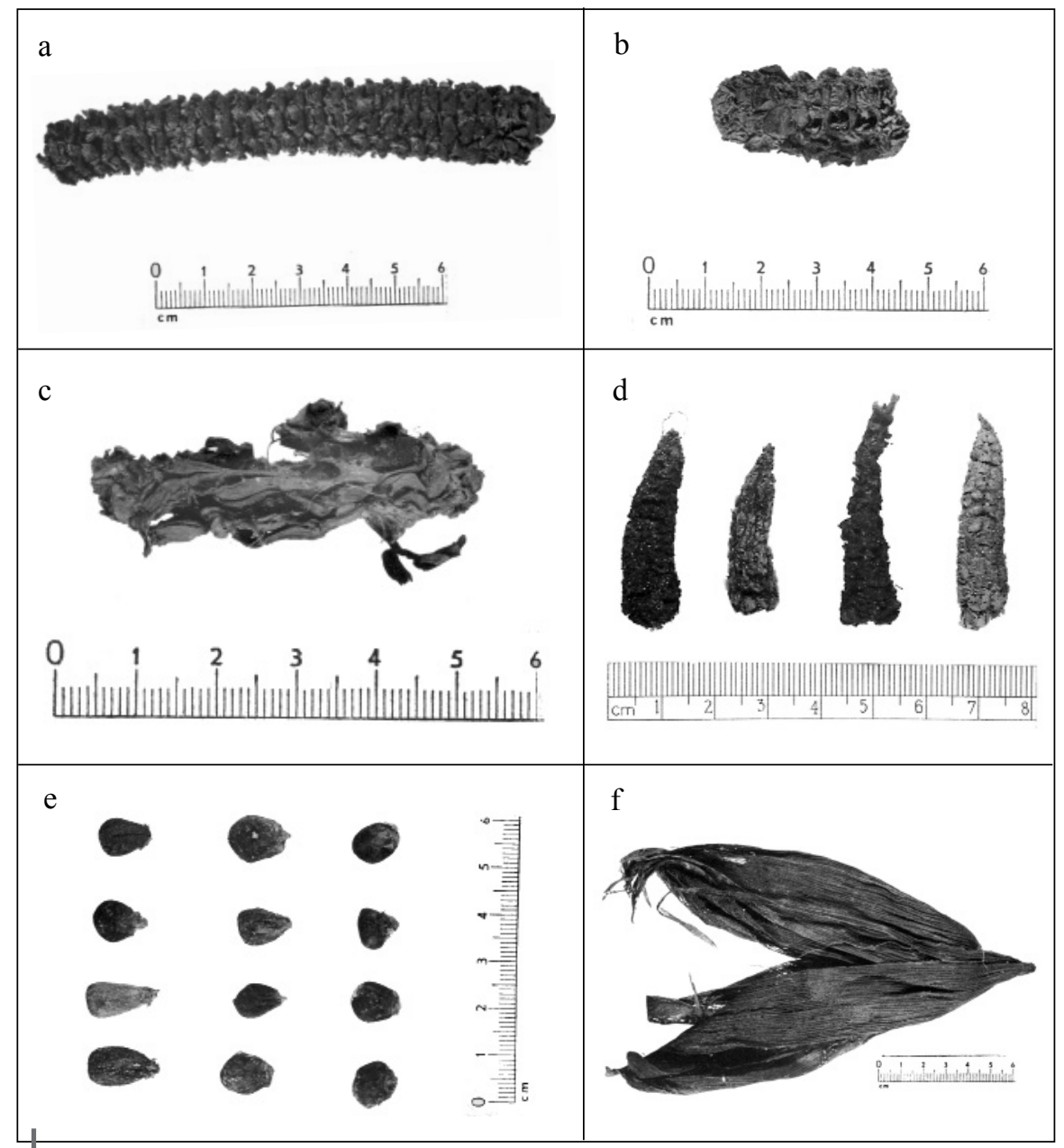

Figura 20 - a: Coronta de Proto-Rabo se Zorro; b: Posible coronta de Proto-Chullpi o de una de sus razas emparentadas cruzada con Proto-Pagaladroga; c: Coronta primitiva ramificada con características de tassel seed; d: Fragmento de «muñecas»; e: Granos de maíz; f: Panca de maíz

Figuras 20a-20d, 20f: Fotos Duccio Bonavia; Figura 20e: Foto Laura W. Johson-Kelley

de ancho y $4 \mathrm{~mm}$ de largo. Tienen abundantes barbas de color púrpura, que además son gruesas. Las espiguillas masculinas que posee forman una gluma externa córnea. El raquis central da la impression de coalescencia o fusión de por lo menos dos ramas laterales. Tiene una estructura de hasta 4 rangos (hileras) y el número de granos que podría soportar es de 4 por hilera. La cantidad de ramificaciones secundarias es de 4 . Estas tienen en su base granos e inflorescencias femeninas y en la parte superior solo inflorescencias (espiguillas) masculinas. (Ver fig. 20c).

Finalmente se han encontrado cinco fragmentos de «muñecas», es decir mazorcas que no han llegado a desarrollarse por falta de agua o de polinización (fig. 20d). 
Hay 33 granos que se pudieron estudiar (en la fig. 20e se muestran 12 de ellos). En la Tabla 6 se puede ver su mayor dimensión que corresponde a la longitud. El ancho fluctúa entre 7 y $9 \mathrm{~mm}$ y el espesor entre 4 y $7 \mathrm{~mm}$. El color de 2 de ellos es café, rojo en 13 y púrpura en 18, lo cual nos muestra una vez más que más del 50 \% de la población tiene genes de coloración púrpura ya que el pericarpio es parte del tejido contribuido por el genotipo materno.

Tabla 6 - Distribución de longitud de granos de maíz en mm

\begin{tabular}{|l|l|l|l|}
\hline Grupo de longitud & 7 a 9 & 10 a 12 & 13 a 15 \\
\hline Cantidad & 8 & 16 & 6 \\
\hline
\end{tabular}

Hay algunos granos imbricados que tienen el endospermo duro (flint) amarillo y blanco en la capa externa y harinoso interno, mostrando que por el tamaño del grano y la estructura, esta población está en transición entre un tipo de maíz primitivo usado como reventador y otro más reciente empleado para tostado.

Una de las pancas que se ha encontrado tiene 6 hojas (fig. 20f). Desde la inserción hasta la punta mide $20 \mathrm{~cm}$. Es de color púrpura diluido, muestra 10 nervaduras exteriores por cm (que corresponde al índice de venación) y 9 en el interior. La segunda panca es incompleta y tiene solo tres hojas (Fig. 21a), con una longitud de $14 \mathrm{~cm}$. Muestra dos tipos de nervaduras bien visibles y gruesas y entre ellas hay algunas que son delgadas. En la hoja interior en $2 \mathrm{~cm}$ hay 4 nervaduras gruesas paralelas y el total (incluyendo las gruesas) es de 14. Mientras que en la hoja exterior hay 6 nervaduras en $1 \mathrm{~cm}$.

El tallo que se ha recuperado es de color rojo, tiene tres filas de raíces adventicias, ocho raíces en el círculo superior, siete en el segundo y siete en el tercero. La longitud de los primeros entrenudos es de $3 \mathrm{~cm}$, del segundo 8,5 cm y del tercero 14,8 cm. El diámetro del primer entrenudo es de $11 \mathrm{~mm}$, el del segundo es de $11 \mathrm{~mm}$ y el tercero de $12 \mathrm{~mm}$. La vaina de la hoja que nace en el segundo entrenudo tiene un índice de venación de 12. En el segundo entrenudo aparecen seis protuberancias que pueden ser el comienzo de raíces adventicias que no llegaron a manifestarse. También en el segundo entrenudo hay siete orificios de salida de larvas de insectos perforadores y la medula está completamente comida (fig. 21b; uno de los orificios está señalado por la flecha). Es possible que se trate de Heliothis zeae. Estos agujeros miden entre 1,5 y $2 \mathrm{~mm}$. En el tercer entrenudo hay por lo menos dos orificios de salida. Esto está demostrando la alta infestación de insectos barrenadores, que son típicos de los cultivos de verano en el valle de Huarmey.

\section{- Fabaceae}

De esta Familia hay legumbres silvestres y domésticas. De las domésticas se ha podido identificar dos semillas de Canavalia sp., es decir lo que se conoce vulgarmente como «pallar de los gentiles» (fig. 21c). Hay además cinco fragmentos de cotiledones y veinte de cáscara. A juzgar por las medidas de las semillas (Tabla 7) 


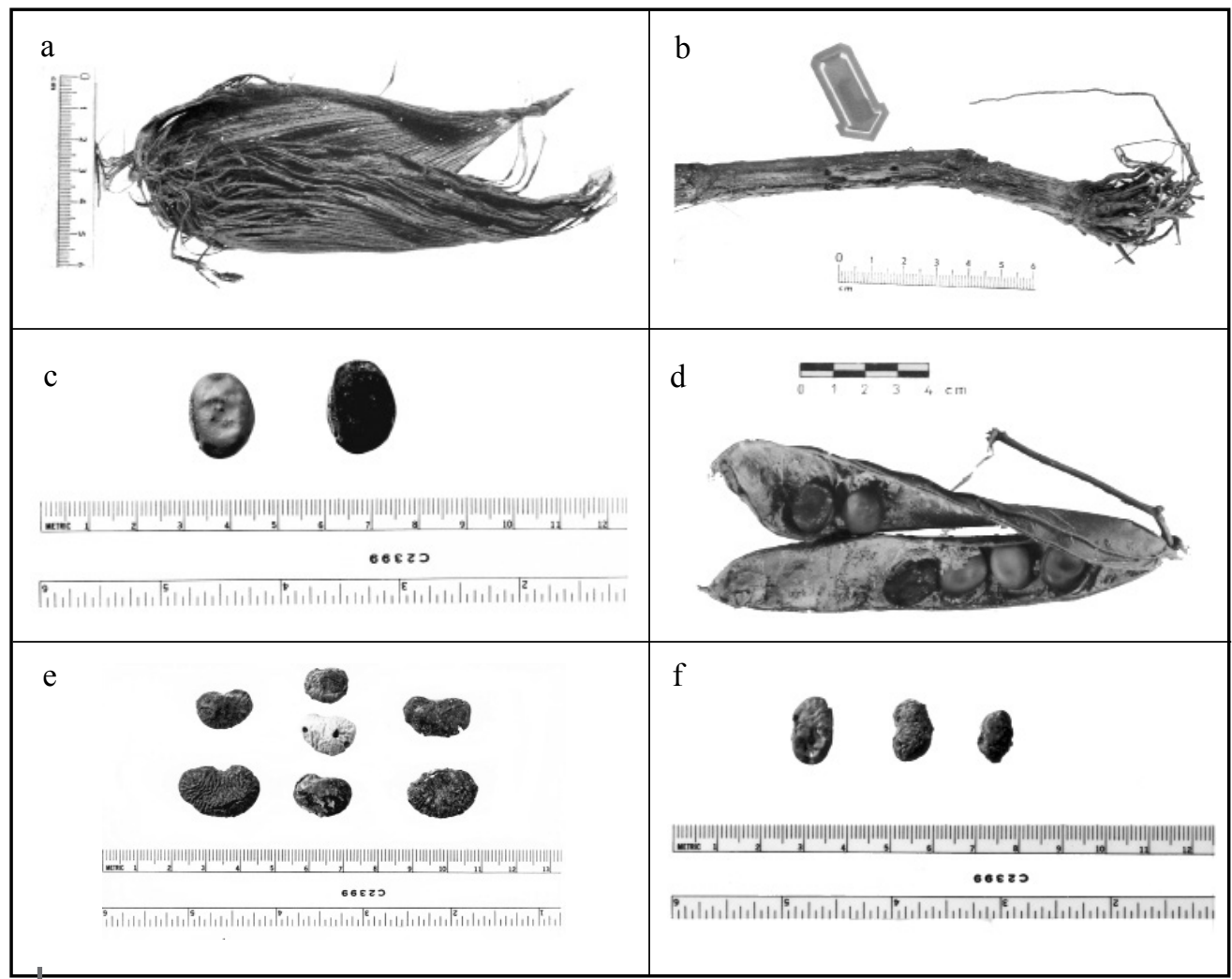

Figura 21 - a: Panca incompleta de maíz; b: Tallo de maíz. La flecha indica el orificio de salida de una larva de insecto perforador; c: Semilla de Canavalia sp.; d: Canavalia plagiosperma Piper; e: Semillas de pallar; f: Semillas de Phaseolus vulgaris

Figuras 21a-21b y d: Fotos Duccio Bonavia; Figuras 21c, e-f: Fotos Laura W. Johson kelley

debe tratarse de C. plagiosperma (vide Sauer \& Kaplan, 1969: 417). También se ha encontrado una vaina completa con sus seis granos de Canavalia plagiosperma Piper que ha sido identificada por Timothy Plowman (fig. 21d) (Vide Purseglove, 1969).

Hay también siete semillas completas de Phaseolus lunatus, es decir pallar (fig. 21e), y tres de Phaseolus vulgaris, fréjol (fig. 21f). Sus características pueden verse en la Tabla 7. Hay también algunas vainas de Phaseolus sp. La identificación de los Phaseolus ha sido certificada por Lawrence Kaplan.

\section{Solanaceae}

El ají, Capsicum sp., está representado por un fruto completo (fig. 22a) y dos fragmentos, más siete semillas completas (en la fig. 22a se muestran 4 de ellas) y un fragmento. Sus medidas pueden verse en la Tabla 8. Emma Cerrate de Ferreyra piensa que se trata de Capsicum frutescens. 
Historia de un campamento del Horizonte Medio de Huarmey, Perú (PV35-4)

Tabla 7 - Medidas de las semillas de Canavalia y Phaseolus

\begin{tabular}{|c|c|c|c|c|c|}
\hline Especies & $\begin{array}{c}\text { Longitud } \\
(\mathrm{mm})\end{array}$ & Ancho $(\mathrm{mm})$ & Grosor $(\mathrm{mm})$ & $\mathbf{L x A} / \mathbf{G}$ & Color \\
\hline \multirow{2}{*}{ Canavalia sp. } & 19,07 & 14,78 & 8,14 & 34,63 & Negro \\
\hline & 17,47 & 13,14 & 7,91 & 29,02 & Marrón rojizo \\
\hline Promedio & 18,27 & 13,96 & 8,03 & 31,83 & \\
\hline \multirow{7}{*}{$\begin{array}{l}\text { Phaseolus } \\
\text { lunatus }\end{array}$} & 23,24 & 14,64 & 6,64 & 51,24 & Negro \\
\hline & 20,28 & 14,09 & 6,70 & 42,65 & Negro \\
\hline & 12,36 & 10,09 & 7,12 & 17,52 & Negro/Rojo \\
\hline & 19,12 & 11,20 & 8,15 & 26,28 & Rojo oscuro \\
\hline & 16,00 & 10,49 & 6,99 & 24,01 & Rojo oscuro \\
\hline & 16,39 & 11,41 & 6,98 & 26,79 & Canela \\
\hline & 16,09 & 11,39 & ------ & ----- & $\begin{array}{c}\text { Negro/marrón } \\
\text { rojizo }\end{array}$ \\
\hline Promedio & 17,64 & 11,90 & 7,10 & 31,42 & \\
\hline \multirow{3}{*}{$\begin{array}{l}\text { Phaseolus } \\
\text { vulgaris }\end{array}$} & 14,65 & 8,73 & 6,62 & 19,32 & Marrón rojizo \\
\hline & 11,91 & 7,32 & 5,29 & 16,48 & Marrón rojizo \\
\hline & 15,44 & 9,30 & ----- & ---- & Marrón rojizo \\
\hline Promedio & 14,00 & 8,45 & 5,96 & 17,90 & \\
\hline
\end{tabular}

Tabla 8 - Medidas de las semillas de Capsicum

\begin{tabular}{|c|c|c|c|}
\hline Longitud $(\mathbf{m m})$ & Longitud $(\mathbf{m m})$ & Longitud $(\mathbf{m m})$ & Longitud $(\mathbf{m m})$ \\
\hline 4,11 & 3,98 & 4,14 & 3,58 \\
\hline 4,13 & 4,19 & 3,74 & 4,02 \\
\hline 3,50 & 3,86 & 3,37 & 3,92 \\
\hline Promedio & 3,88 & \multicolumn{3}{|l}{} \\
\hline
\end{tabular}

\section{1. 2. Plantas industriales cultivadas}

Cucurbitaceae

Como se ha señalado en el acápite «Cucurbitaceae» solo se ha encontrado veinte fragmentos de cáscaras de Lagenaria siceraria que estuvieron mezcladas con las de Cucurbita sp. (fig.18c).

Malvaceae

Un pequeño fragmento de fibra parece ser de algodón, Gossypium barbadense. Sin embargo no se ha encontrado sus semillas. 


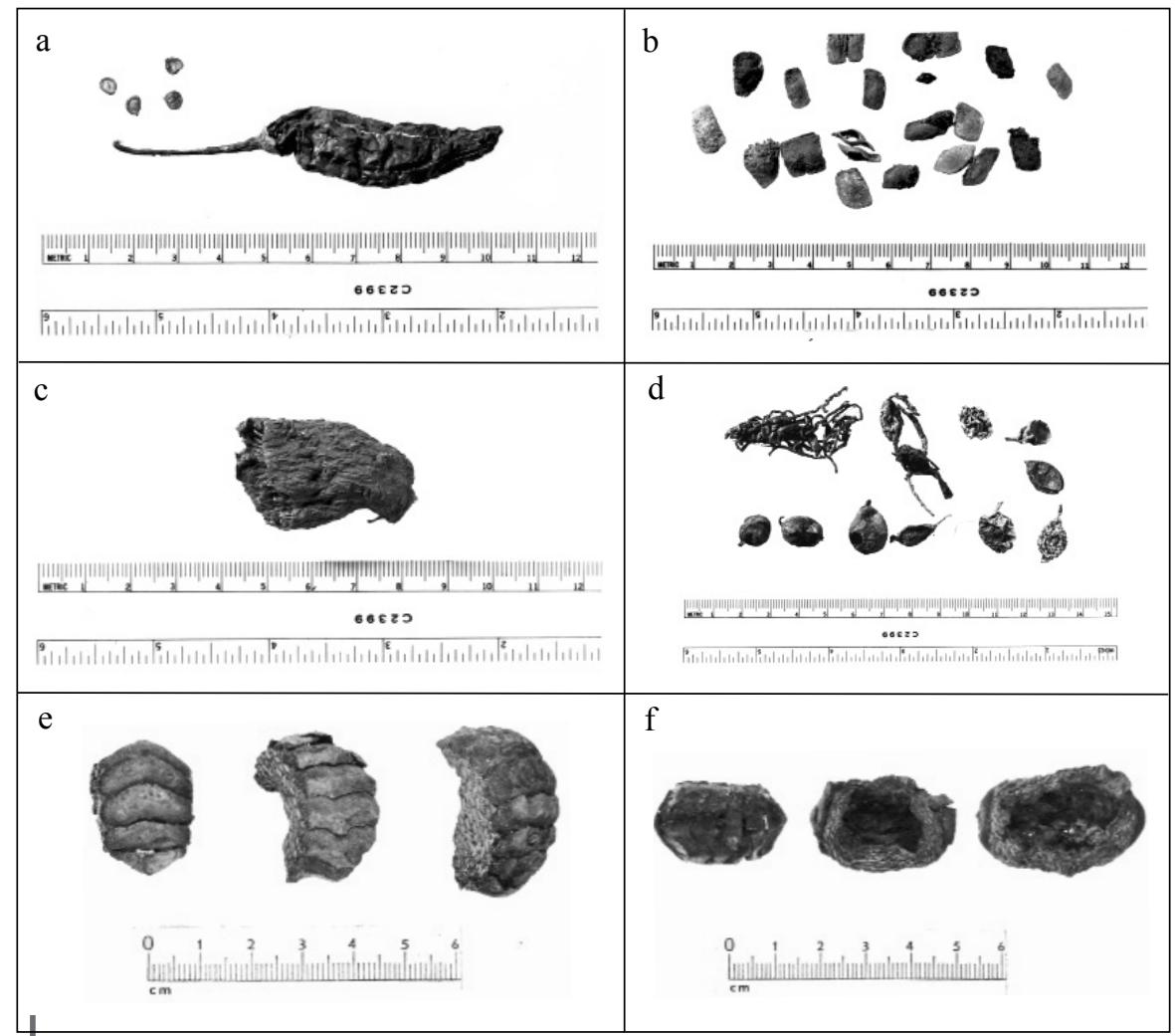

Figura 22 - a: Fruto y semilla de Capsicum sp.; b: Semillas de algarrobo; c: Tubérculo no identificado; d: Algas marinas (sargazo); e: Quitones; f: Quitones

Fifuras 22a-22d: Fotos laura w. Johson Kelley; Figuras 22e-f: Fotos Duccio Bonavia

\section{1. 3. Plantas alimenticias recolectadas}

\section{Mimosaceae}

Hay veintiún semillas de algarrobo, Prosopis pallida, con su endocarpio (fig. 22b); además una vaina completa y quince fragmentos de Prosopis sp. Esta es una planta que crece silvestre, pero que fue utilizada por el hombre.

\section{1. 4. Maleza}

\section{Asteraeceae}

Se ha podido identificar dos pequeñas cabezuelas y siete semillas de especies de malezas de esta Familia, lo que evidentemente no parece tener ninguna significación económica.

\section{Euphorbiaceae}

De esta Familia se ha identificado dos géneros, el primero con una especie que ya se ha mencionado (vide supra «Euphorbiaceae») y el segundo con dos. Es 
así que hay una semilla y una cápsula completa y tres fragmentos de Euphorbia heterophylla, que es un hierbajo común. Además hay una semilla que parece ser de Euphorbia serpens, aunque no hay seguridad de esta identificación.

\section{1. 5. Otros}

En la muestra hay también varios tubérculos que no han podido ser identificados (fig. 22c). Ellos tienen la superficie erosionada. Un estudio microscópico de los granos de almidón podría ayudar para su identificación, pero solo si ellos no han sido expuestos al calor por los que los utilizaron, pues durante la cocción estos revientan, limitando las posibilidades del análisis.

\section{1. 6. Lessoniaceae}

Finalmente en el sitio se encontró una importante cantidad de algas marinas, conocidas como sargazo, aunque se les llama también aracanto o alacanto (Macrocystis pyrifera var.humboldtii), que han sido traidas al campamento. En la gran mayoría de los casos el talo está completo, pero hay también frondes (fig. 22d).

\section{RESTOS ANIMALES}

\section{1. Mollusca}

\section{1. 1. Polyplacophora}

Cerca del hogar, pero esparcidos, encontramos treinta quitones (barquillos, Enoplochiton niger) muy bien conservados con sus placas y cinturón o cíngulo (fig. 22e). A todos les falta el pie y el contenido visceral del que han quedado solo restos. También se han encontrado placas sueltas de barquillos (Enoplochiton niger, Chitonidae, 0,3\%) y en mayor cantidad de barbones (Acanthopleura echinata, Chitonidae, 0,6 \%). La mayoría son de tamaño mediano y hay algunos pequeños. Si se observan cuidadosamente estos restos, se nota claramente que los individuos que comieron los pies de estos poliplacóforos, no tenían un implemento eficiente para sacar la carne de la que han quedado fragmentos (fig. 22f). Además ninguno de ellos tiene huellas de quemado, lo que demuestra que fueron consumidos crudos. A parte de esto hubo una cantidad de conchas de moluscos, que presentamos en términos de porcentaje en función del peso de las mismas en la Tabla 9.

Es de notar que en el caso de los Poliplacóforos, para el cálculo de porcentaje, se ha utilizado solo las placas sueltas que se encontraron entre los restos de los otros moluscos, y en ello no están incluidos los 30 especímenes completos que están señalados más arriba. Aunque fueran considerados, las cifras no variarían sustancialmente. 
Tabla 9 - Peso de concha de moluscos y artrópodos expresado en porcentaje

\begin{tabular}{|l|c|}
\hline Semimytilus algosus & 8,3 \\
\hline Choromytilus chorus & 0,1 \\
\hline Aulacomya ater & 37,3 \\
\hline Perumytilus purpuratus & 23,4 \\
\hline Protothaca thaca & 0,009 \\
\hline Donax peruvianus & 0,09 \\
\hline Fissurella crassa & 2,5 \\
\hline Fissurella limbata & 9,7 \\
\hline Fissurella maxima & 2,8 \\
\hline Scurria parasitica & 0,5 \\
\hline Tegula atra & 1,2 \\
\hline Crepipatella dilatata & 0,3 \\
\hline Thais hemastoma & 0,3 \\
\hline Concholepas concholepas & 1,8 \\
\hline Enoplochiton niger & 0,3 \\
\hline Acanthopleura echinata & 0,6 \\
\hline Balanus sp. & 0,09 \\
\hline Chtamalus sp. & 0,09 \\
\hline Fragmentos no identificados & 10,621 \\
\hline
\end{tabular}

\section{2. Arthropoda}

\section{2. 1. Crustacea}

Hubo también una pequeña cantidad de crustáceos, conocidos como pico de loro (Balanus sp., Balanidae; 0,09 \%) y Chtamalus sp. (Balanidae; 0,09 \%). Además fragmentos de cangrejito violado (Petrolisthes violaceus, Porcellanidae), araña de las rocas, araña de mar o maimacho (Grapsus grapsus, Grapsidae), cangrejo colorado conocido también como cangrejo criollo o violáceo (Platyxanthus orbignyi, Xantidae) y cangrejo araña (Acanthonix petiverii, Majidae).

\section{3. Varios}

También hallamos un muymuy completo (Emerita analoga, Hippidae) y restos de una estrella de mar (Asteroidea).

Se debe señalar que esta información sobre los restos animales ha sido incluida parcialmente y a manera de comparación en el informe que se refiere al vecino 
sitio precerámico Los Gavilanes (vide Bonavia, 1982: Cuadro 18: 189; Cuadro 24: 385).

Ha quedado un 10,621 \% de material sin clasificar, por ser demasiado fragmentado.

\section{4. Chordata}

Asimismo hemos encontrado 65 huesos o fragmentos de ellos de cordados. Se han podido identificar 13. En este caso se consignará la cantidad de huesos que se ha recuperado.

\section{4. 1. Pisces}

De los restos de peces se han identificado Rhinobatos sp. (Rhinobatidae) (1) que podría ser lo que se conoce vulgarmente como guitarra (R. planiceps), Engraulidae o sea anchovetas (2), Sciaena deliciosa (Sciaenidae) o lorna (1) y Pimelometopon sp. (Labridae) o vieja (1).

\section{4. 2. Aves}

De las aves solo se han podido reconocer Pelecanus sp. (Pelecanidae) o pelicano (5) y Sula sp. (Sulidae) o piquero (2). De este ultimo se encontró además un cráneo completo.

\section{4. 3. Mammalia}

\section{- Cetacea}

De mamíferos hubo únicamente cf. Cetacea (Delphinidae) (1).

No se han logrado identificar 2 huesos de aves y 50 de peces.

Si estas cifras se consideran en términos de porcentajes, los peces representan el $84,6 \%$ del total, las aves el $13,8 \%$ y los mamíferos tan solo el 1,5\%.

Es muy importante señalar que el hueso de cetáceo muestra huellas que parecen ser de mascado y además la fractura por sus características debió ser intencional. Los restos de Rhinobatos y de Pimelometopon están quemados, lo que indica que los peces fueron cocidos probablemente sobre las brasas.

\section{PALEOESCATOLOGÍA}

\section{1. Camelidae}

En la zona sur, casi al límite de nuestra excavación, localizamos una concentración de coprolitos animales. En conjunto pesan 100 gr, pero hay que tomar en cuenta que este peso corresponde a material seco. Estos restos son idénticos a los hallados en Los 
Gavilanes y los hemos comparado con los de camélidos actuales. Son definitivamente de llama (Lama glama). Se ha analizado dos muestras tomadas al azar.

La metodología empleada para efectuar los análisis de este granulado fecal, ha sido explicada con lujo de detalles en un trabajo anterior (lege Jones \& Bonavia, 1992: 837-838) de modo que no consideramos necesario repetirlo. Queremos solo recordar que para el análisis se añadió a cada muestra una espora trazadora de Lycopodium spp. (vide Tabla 10). Esto se hizo por dos razones. En primer lugar porque la presencia de estas esporas trazadoras en las muestras, después de la extracción química, sirve para verificar que el polen no fue destruido accidentalmente durante el proceso de extracción. Y, segundo, dado que se conoce la cantidad de esporas añadida a cada muestra (11,300 \pm 400 granos por tableta), es fácil obtener el valor de concentración, en términos de granos de polen, por cada gránulo fecal o gramo (Vide también Jones, 1993: 31).

Como es sabido, los camélidos tienen una digestión más completa que los otros rumiantes avanzados (San Martín \& Bryant, 1987: 15; San Martín et al., 1989: 108), lo que dificulta las identificaciones de los restos contenidos en los coprolitos. Además, cuando se hizo el estudio (Jones, 1990), no se contó con material comparativo que permitiera realizar análisis macroscópicos. De modo que concentramos nuestros esfuerzos en el aspecto polínico. Los resultados se pueden apreciar en la Tabla 10. Allí se puede constatar que los granos de polen que predominan corresponden a las Asteraceae de espina corta (46,5 \% y 48,8 \%). En segundo lugar está un tipo de polen que no ha podido ser identificado y que por eso se ha denominado Desconocido A (20,2 \% y 15,5\%) y sobre el que habría que investigar. En tercer lugar están las Poaceae (11\% y 9,5\%) entre las que no incluimos al maíz. Las Asteraceae de espina larga tienen un porcentaje importante $(12,3 \%)$ en una muestra, mientras que en la otra es mucho menor $(7,4 \%)$. En cantidad inferior tenemos el polen de Cheno/Am en una muestra $(3,1 \%)$. Hemos optado por utilizar esta denominación para referirnos a los tipos combinados de polen de Chenopodiaceae y Amaranthus, como ha sugerido Martin (1963) ya que el polen de esta familia y género de plantas es muy similar en apariencia y a veces son difíciles de distinguir. En el mismo rango tenemos polen de maíz (Zea mays, $2,2 \%$ ). En la otra éste está presente también, pero en cantidad inferior (1,3\%).

En proporciones pequeñas en una muestra tenemos polen de Cheno/Am (1,4\%), Alnus (1,4\%), Anacardiaceae (1,8\%) y un tipo de polen no identificado que hemos denominado Desconocido (1,4\%). Mientras que en la otra muestra hay polen de Fabaceae $(1,8 \%)$. En cantidades muy pequeñas en una muestra hay polen de Campanulaceae $(0,9 \%)$, de Convolvulaceae $(0,4 \%)$, Cucurbitaceae $(0,4 \%)$, Cyperaceae $(0,4 \%)$, Malvaceae $(0,4 \%)$, Nyctaginaceae $(0,4 \%)$, Poligonaceae $(0,4 \%)$ y Solanaceae $(0,4 \%)$. Mientras que en la otra hay granos de polen de Anacardiaceae $(0,4 \%)$, Brassicaceae $(0,4 \%)$, Cyperaceae $(0,4 \%)$. Las Rosaceae se encuentran en ambas muestras $(0,4 \%$ y $0,9 \%)$.

En la primera muestra no se ha podido identificar el 3,9\% de granos de pollen y en la segunda el 3,6 \%. 
Historia de un campamento del Horizonte Medio de Huarmey, Perú (PV35-4)

Tabla 10 - Tipos de polen encontrados en los excrementos de Camelidae

\begin{tabular}{|c|c|c|c|c|}
\hline \multirow{2}{*}{ Taxón } & \multicolumn{2}{|c|}{ Muestra 1} & \multicolumn{2}{|c|}{ Muestra 2} \\
\hline & Cantidad & $\%$ & Cantidad & $\%$ \\
\hline Zea mays & 5 & 2,2 & 3 & 1,3 \\
\hline Poaceae & 25 & 11,0 & 21 & 9,5 \\
\hline Asteraceae EC & 106 & 46,5 & 107 & 48,8 \\
\hline Asteraceae EL & 17 & 7,4 & 27 & 12,3 \\
\hline Cheno-Am & 3 & 1,4 & 7 & 3,1 \\
\hline Alnus & 3 & 1,4 & & \\
\hline Anacardiaceae & 4 & 1,8 & 1 & 0,4 \\
\hline Brassicaceae & & & 1 & 0,4 \\
\hline Campanulaceae & & & 2 & 0,9 \\
\hline Convolvulaceae & 1 & 0,4 & & \\
\hline Cucurbitaceae & 1 & 0,4 & & \\
\hline Cyperaceae & & & 1 & 0,4 \\
\hline Fabaceae & & & 4 & 1,8 \\
\hline Malvaceae & 1 & 0,4 & & \\
\hline Nyctaginaceae & 1 & 0,4 & & \\
\hline Polygonaceae & 1 & 0,4 & & \\
\hline Rosaceae & 1 & 0,4 & 2 & 0,9 \\
\hline Solanaceae & 1 & 0,4 & & \\
\hline Desconocido «A» & 46 & 20,2 & 34 & 15,5 \\
\hline Desconocido & 3 & 1,4 & 1 & 0,4 \\
\hline Indeterminado & 9 & 3,9 & 8 & 3,6 \\
\hline Total & 228 & 100,0 & 219 & 100,0 \\
\hline Lycopodium & 587 & & 155 & \\
\hline $\begin{array}{l}\text { Valor de concentración (granos por } \\
\text { gramo) }\end{array}$ & 21,945 & & 79,829 & \\
\hline
\end{tabular}

Asteraceae E.C.: Tipo de polen de la familia Asteraceae con espina corta $(-1,5 \mu \mathrm{m})$ Asteraceae E.L.: Tipo de polen de la familia Asteraceae con espina larga $(+1,5 \mu \mathrm{m})$ Desconocido y Desconocido «A»: Tipos de polen de los que no hay muestras en las colecciones peruanas utilizadas para este estudio.

Cheno-Am: Tipos combinados de polen de la familia Chenopodiaceae/género Amaranthus 


\section{2. Homo sapiens sapiens}

En los alrededores del fogón se encontraron tres coprolitos. Su análisis ha sido incluido en el estudio que se publicó sobre Los Gavilanes (vide Weir \& Bonavia, 1985); por razones prácticas extractaremos aquí los resultados. Pero en lo que se refiere a la metodología de estudio y a cualquier otro detalle, remitimos al lector al escrito mencionado.

El coprolito $\mathrm{n} .^{\circ} 51$ tuvo un peso de $80,59 \mathrm{gr}$, el n. ${ }^{\circ} 52$ 36,29 gr y el n. ${ }^{\circ} 5310,24 \mathrm{gr}$. Este es el peso seco, antes de la rehidratación de las heces. En el momento del hallazgo, la muestra fecal n. ${ }^{\circ} 51$ estaba completamente recubierta de arena en la parte exterior y tenía adherido un pelo, probablemente humano. La n. ${ }^{\circ} 52$ tenía adheridos muchos pelos, probablemente humanos, y restos pequeños de color amarillo, que a simple vista parecían fragmentos de corteza vegetal. Y, finalmente, la . $^{\circ} 53$ presentaba en la superficie, a simple vista, una serie de pequeños fragmentos de color negro de una materia dura.

Los análisis efectuados para establecer el origen de estos restos fecales, han dado como resultado que uno de ellos (n. ${ }^{\circ}$ 52) es humano (es decir de origen humano seguro según todas las características), otro $\left(n .^{\circ}\right.$ 53) es probablemente humano (o sea tiene $90 \%$ de posibilidades o más de serlo) y el tercero $\left(\mathrm{n}^{\circ}{ }^{\circ} 51\right)$ es posiblemente humano (es decir tiene $662 / 3 \%$ de posibilidades de serlo). Se debe señalar, sin embargo, que el hecho que en los coprolitos $n .^{\circ} 51$ y 52 se haya detectado la presencia de Trichuris trichura (vide infra), nos da la seguridad que son de origen humano, pues según Faust et al. (1979: 273) «[e]l hombre es el único huésped comprobado de este parásito...» (Lege también Reinhard, 1990: 155). Para mayores detalles vide Cuadro 1 en Weir \& Bonavia (1985: 127).

\section{2. 1. Palinología y otros restos}

En función de los análisis efectuados, el contenido de los coprolitos humanos es el siguiente: en el $\mathrm{n} .^{\circ} 51$ se han contado 50 granos de polen, en el $\mathrm{n}{ }^{\circ} 52,79 \mathrm{y}$ en el n. 53,6 . Todos ellos corresponden a tipos de polen no arbóreo (Tabla 11).

En el coprolito $n .^{\circ} 51$ hubieron dos granos de polen de Cheno/Am (que representan el $4 \%$ ). Ya hemos explicado las razones por las que utilizamos este término, y por qué tratamos juntos los polenes de las Chenopodiáceas y del Amaranthus (vide supra). Además, hubieron 3 granos de Poaceae (que constituyen el $6 \%$ ) y 45 de Protaceae (que significan el $90 \%$ ).

En el coprolito . $^{\circ} 52$ se encontraron 79 granos de polen de Protaceae que representan el $100 \%$. Finalmente en el n. ${ }^{\circ} 53$ hubieron 2 granos de polen de Asteraceae de espina corta (que son el 33,3\%), 2 de Poaceae (que significan el $33,3 \%$ ) y 2 de Potamogetonaceae (que indican el 33,3\%) (Tabla 11).

Además en los coprolitos n. ${ }^{\circ} 51$ y 53 se encontraron esporas de Pteridofitas y en el n. $^{\circ} 52$ esporas de hongos. En las tres muestras hubieron fragmentos de huesos y escamas de peces, restos de huesos y pelos de mamíferos, trozos de 
Tabla 11 - Contenido polínico de los coprolitos humanos

\begin{tabular}{|c|c|c|c|c|c|c|}
\hline \multirow{2}{*}{ Familia } & \multicolumn{2}{|c|}{ Muestra.$^{\circ} 51$} & \multicolumn{2}{|c|}{ Muestra.$^{\circ} 52$} & \multicolumn{2}{|c|}{ Muestra ${ }^{\circ} .^{\circ} 53$} \\
\hline & n. ${ }^{\circ}$ de granos & $\%$ & n. ${ }^{\circ}$ de granos & $\%$ & n. ${ }^{\circ}$ de granos & $\%$ \\
\hline $\begin{array}{l}\text { Chenopodiaceae/ } \\
\text { Amaranthus }\end{array}$ & 2 & 4 & & & & \\
\hline Asteraceae E.C. & & & & & 2 & 33,3 \\
\hline Poaceae & 3 & 6 & & & 2 & 33,3 \\
\hline Potamogetonaceae & & & & & 2 & 33,3 \\
\hline Protaceae & 45 & 90 & 79 & 100 & & \\
\hline Esporas de Pteridofitas & + & & & & + & \\
\hline Esporas de hongos & & & +++ & & & \\
\hline Número total de granos & 50 & & 79 & & 6 & \\
\hline$\%$ total & & 100 & & 100 & & 100 \\
\hline
\end{tabular}

conchas de moluscos univalvos y bivalvos, restos carbonizados, carbón y pedazos de madera.

En los coprolitos n. 52 y 53 se han hallado también huesos y plumas de aves, en el $n .^{\circ} 52$ fibras de dicotiledóneas y de monocotiledóneas y, finalmente, en el n. 51 se identificaron semillas de Rosaceae (Tabla 12).

Finalmente cabe señalar que en el coprolito n. ${ }^{\circ} 51$ se identificó la pata de un ácaro de vida libre. El artrópodo llegó probablemente atraido por el olor de las heces y quedó atrapado. Además, en los tres especímenes se encontró una significativa cantidad de arena. Si bien una parte proviene probablemente de la parte externa, donde se adhirió al momento que la materia fecal fue depositada sobre la superficie arenosa, otra cantidad procede seguramente de la ingestión de

Tabla 12 - Contenido de plantas y animales en los coprolitos humanos

\begin{tabular}{|l|c|c|c|}
\hline \multirow{2}{*}{ Restos identificados } & \multicolumn{3}{c|}{ Número de la muestra } \\
\cline { 2 - 4 } & $\mathbf{5 1}$ & $\mathbf{5 2}$ & $\mathbf{5 3}$ \\
\hline Huesos de aves, plumas & & + & + \\
\hline Huesos de peces, escamas, etc. & + & + & + \\
\hline Huesos de mamíferos, pelos, etc. & + & + & + \\
\hline Concha de moluscos univalvos y bivalvos & + & + & + \\
\hline Restos carbonizados, carbón, fragmentos de madera & + & + & + \\
\hline Fibras de dicotiledóneas & & + & \\
\hline Fibras de monocotiledóneas & & + & \\
\hline Semillas de Rosaceae & + & & \\
\hline
\end{tabular}


mariscos, pues es muy probable que no fueron lavados, y quizá de otros alimentos que fueron comidos en la playa.

\section{2. 2. Parasitología}

En las muestras n. ${ }^{\circ} 51$ y 52 se encontraron muchos huevos de Trichuris trichiura (sin. Trichocephalus dispar). Estos huevos, bien conservados, fueron fácilmente identificados por su forma elipsoide característica, su envoltura o cáscara gruesa de tres capas, su envoltura externa de color marrón amarillento por pigmentos de bilis y que presentan en cada polo un tapón albuminoso y traslúcido procidente, que le da un aspecto parecido al de un limón. Las medidas de estos huevos varían en promedio entre $48 \mu \mathrm{m}$ (micrómetros) y $60 \mu \mathrm{m}$ por $25 \mu \mathrm{m}$ y $31 \mu \mathrm{m}$. La cubierta vitelina externa se ha perdido debido a la sequedad, pero ha sido posible ver la sustancia granulosa interior, o en algunos especímenes, restos de los embriones (fig. 23; ampliación x400). La excelente conservación de los ejemplares en los coprolitos, aparentemente es el resultado de la alta resistencia natural de los huevos a la sequedad; el proceso de embriogénesis puede tomar 10 días a lo más en el medio ambiente, hasta llegar al estadio de larva infectante. La eclosión se produce en el tracto digestivo y el papel de las secreciones gástricas y duodenales es importante (Patrucco et al., 1983: 394).

Además en la muestra n. ${ }^{\circ} 51$ se verificó la presencia de ooquistes de Cryptosporidium sp. (Ortega \& Bonavia, 2003: 635). Es importante anotar que en el informe preliminar (Ortega \& Bonavia, 2003), por error se señaló el hallazgo de Enterobius vermicularis en este coprolito.

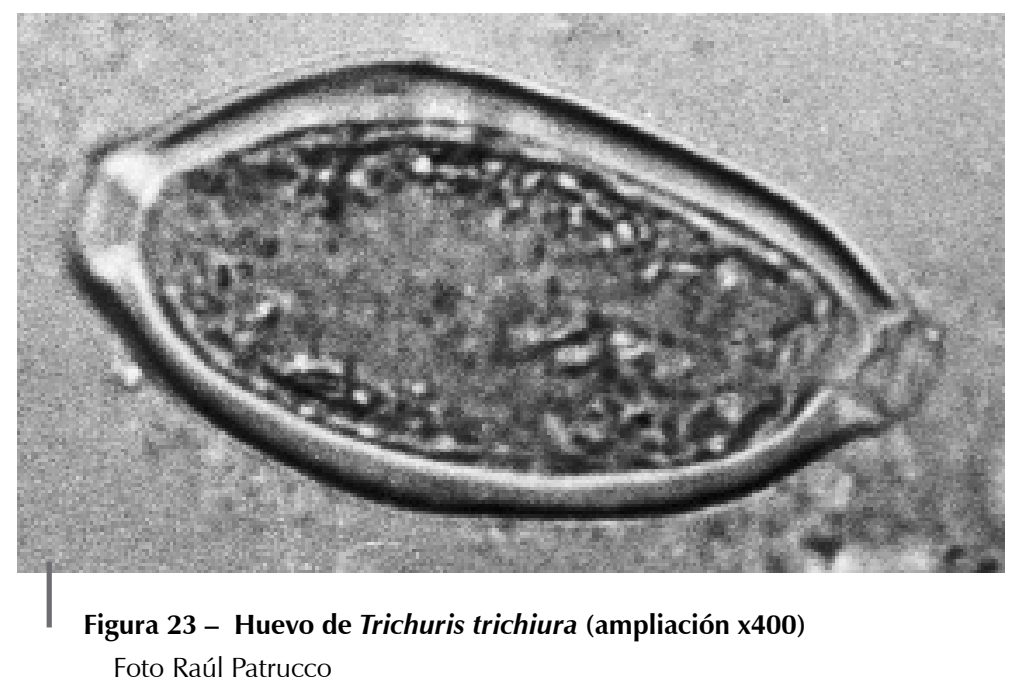

\section{COMENTARIOS ADICIONALES}

La primera pregunta que se debe hacer y a la que es muy difícil contestar con un margen razonable de seguridad, es qué vino hacer este grupo humano cerca 
de la playa. Pues es claro por todas las evidencias que se tienen, que se trata de una cantidad reducida de personas que estuvo allí un tiempo muy corto. Lo más probable es que ellos provenían del vecino valle de Huarmey y para explicar las causas que los empujaron a ello podemos pensar en dos posibilidades. O fueron habitantes de la parte media o alta del valle que no tenían familiaridad con el mar y venían a pasar un tiempo de descanso o se instalaron allí con la tarea de pescar y mariscar para enviar estos productos marinos al valle. Nos inclinamos por la primera posibilidad por las evidencias que expondremos inmediatamente.

En este sentido es importante recordar que este sitio no es el único en el área, pues Los Gavilanes 2 (PV35-103) y Los Gavilanes 3 (PV35-104) parecen tener las mismas características a juzgar por los restos de superficie. En el primer caso se trata de un yacimiento de $11 \mathrm{~m}$ por $8 \mathrm{~m}$ y en el segundo de una zona circular de $5 \mathrm{~m}$ de diámetro; ambos corresponden al Horizonte Medio y están relativamente cerca de PV35-4, aunque en lugares protegidos de los vientos (Vide Bonavia, 1982: 442).

Pero antes de seguir hay que tratar de responder a otra pregunta: ¿cuántas personas estuvieron allí? Consideramos que en este caso también es imposible dar una respuesta exacta; se puede sin embargo sacar algunas conclusiones en función de las evidencias que se tienen. En primer lugar hay que señalar que, como se dijo al inicio, se excavó solo el $14 \%$ del yacimiento pero, como se recordará, todas las evidencias indican que esa fue la parte más importante de este y donde hubo más basura. Ella, en promedio, tuvo un espesor de $27 \mathrm{~cm}$. Si bien es cierto que pudo haber más fogones en la zona no excavada, ello no parece por las razones que ya se han explicado (vide supra). Suponemos que debieron estar allí como máximo unos diez o doce individuos y que permanecieron en el lugar no más de dos semanas.

La primera razón por la que estimamos que no fueron personas que tuvieron familiaridad con el litoral es por el lugar que escogieron para acampar. Cualquiera que tenga un poco de experiencia sabe que los vientos alisios que soplan en sentido Sureste son característicos de la costa peruana y que traen mucha humedad. De modo que la primera cosa que hay que tomar en cuenta para establecerse, es buscar una protección natural contra este fenómeno. Y uno de los lugares menos aconsejables para ello, son justamente los corredores existentes entre los cerros costeros por los que el viento ingresa hacia el interior con fuerza, dificultando la estada y creando ambientes fríos por las noches, incluso de día cuando hay neblina. El paraje donde estuvo situado el campamento en estudio es justamente uno de estos sitios y ello demuestra un desconocimiento de esta realidad de parte de esos hombres.

Todo indica, repetimos, que hubo solo los dos fogones, uno principal y otro secundario. Ello estaría indicando que se cocinó en el primero por las evidencias que veremos inmediatamente y que el otro por no tener restos de comida y por ser pequeño, como se ha descrito, cumplió otra función, quizá sirvió para calentarse por las noches. De modo que es probable que se durmió en los bordes de la zona inmediata a los fogones. Por los restos de hojas de carrizo y las cañas halladas, se puede suponer que quizá pudo haberse levantado una choza provisoria para protección del viento, si no para todos los que estuvieron allí por lo menos para algunas personas quizá mujeres y niños. 
Se ve que el fogón principal ha sido provisorio, pues no ha sido delimitado por piedras, sino que se cocinó sobre las cenizas y las brasas. Los restos de yuca, camote, maíz, anchoveta y otros peces y hasta algunas aves, así lo están indicando. La grama salada encontrada en importante cantidad y que crece hasta hoy en la laguna fósil cercana (vide Bonavia, 1982: 17), sin duda ha servido como combustible para el fogón como lo están indicando las cenizas, pero al mismo tiempo es muy posible que haya sido utilizada como colchón para aislarse de la arena que en las madrugadas se vuelve fría al perder el calor que absorbe del sol durante el día.

Otro hecho que demuestra que los que acamparon en PV35-4 no fueron gente acostumbrada a vivir en el ambiente de playa, es que se encontró mucho sargazo pero este no mostraba huellas de quemado. Son algas que flotan por sus ampollas de aire en grandes pacas en alta mar y son varadas en considerables cantidades en las playas peruanas (Schweigger, 1964: 197). Durante todos los tiempos precerámicos los pobladores costeros aprovecharon estas algas como combustible (Bonavia, 1982: 346). Y hasta hoy los pescadores que pernoctan las utilizan, pues tienen la característica de quemarse lentamente y mantener el calor. Sin embargo este no fue el uso que se les dio en este sitio y es posible que solo se les haya traido al campamento desde la playa para otro fin, quizá para sentarse o, junto con la grama salada, para formar un colchón para dormir.

Como se ha dicho la lasca y los restos de algunos tejidos que estaban entre los vestigios de este campamento, definitivamente no corresponden a este contexto cultural, y sin duda han sido recogidos de la superficie de Los Gavilanes (PV35-1) que no solo está cerca, sino que se encuentra en el camino si alguien quiere llegar a la playa Huanchaquito desde el valle (vide fig. 1). Los pescadores aún utilizan esta senda tradicional. Hay evidencia que en los tiempos del Horizonte Medio se seguía esta costumbre, pues en la superficie y en la capa superficial de arena eólica de Los Gavilanes se han encontrado fragmentos y hasta cántaros enteros correspondientes al Horizonte Medio 3 (vide Bonavia, 1982: 144-145).

Los excrementos de llama que se han hallado, por la poca cantidad, indican que se trató de un solo animal y que no estuvo allí por mucho tiempo. Es poco probable que se haya quedado constantemente con la gente del campamento. Es posible que era utilizado para ir y venir del valle vecino trayendo agua y frutas y quizá aprovechando para llevar algún pescado desde la playa.

Un hecho que puede llamar la atención es que los ocupantes del sitio no han dejado artefactos. Sin embargo consideramos que esto es lógico, dado que no fue un lugar de habitación estable sino transitorio, de modo que se llevaron consigo lo que habían traído, salvo algo que se les pudo haber extraviado o roto y por eso inservible.

Recordemos que se encontraron solo restos incompletos de 8 recipientes de cerámica. En primer lugar cabe la posibilidad $-\mathrm{y}$ consideramos que ello es muy probable- que el resto pudo estar en la zona alrededor de la central que no hemos excavado e incluso fuera de ella. Por otro lado algunas vasijas pudieron haberse roto en el camino y solo parte llegó al sitio o, aunque esto sea lo menos 
probable, por alguna razón se recogió fragmentos de la superficie durante el trayecto por razones que desconocemos.

Los fragmentos de tejidos que nos han dejado son todos llanos, si excluimos los entrelazados que, insistimos, seguramente fueron recogidos al paso por Los Gavilanes o algún otro yacimiento precerámico en el camino entre el valle y la playa. Han quedado solo pedazos que por alguna razón trajeron consigo, pues evidentemente se llevaron los tejidos completos. En este sentido no sabemos nada de los textiles que fueron de uso común en estos tiempos y que obviamente son muy diferentes a los que se encuentran en las tumbas o en los sitios públicos. Pero es significativo que en Tuquillo (PV35-7) situado cerca de la playa homónima hacia el norte y a relativamente corta distancia de PV35-4 (vide Bonavia, 1982: Mapa 2: 14-15), en el estrato correspondiente al Horizonte Medio también se encontraron tejidos llanos (Bonavia, 1982: 235-236).

Los pedazos de sogas, soguillas y juncos evidentemente son restos de los que fueron empleados para amarrar cosas y se quedaron solo los que se rompieron. En Tuquillo también se encontraron partes de cuerdas y de sogas, la única diferencia es que allí hubo fragmentos de una red (Bonavia, 1982: 235).

Es difícil que los hilos de lana de alpaca hayan llegado en forma accidental al sitio; suponemos que alguien del grupo probablemente estuvo tejiendo y ellos se extraviaron o fueron desechados. Lo mismo pudo haber sucedido con el ovillo de algodón que se perdió en la arena y por eso se quedó. La mota de algodón pudo haber estado en forma accidental entre las cosas de los ocupantes y no sabemos si se trata de algodón doméstico o silvestre, pues este aún se encuentra en el valle de Huarmey (Díaz Celis, 1995: 36).

El collar de conchas de lapa es muy simple y por el diámetro debió pertenecer a una persona muy joven. Por la forma en la que ha sido preparado, parece tratarse de un adorno improvisado hecho a base de restos encontrados en la playa y por alguien que quizá veía por primera vez ese tipo de moluscos que le llamaron la atención.

Los remanentes de plantas alimenticias cultivadas que se han encontrado en el campamento son normales, pues todas ellas han sido utilizadas desde los tiempos precerámicos (se puede comparar la Tabla 3 con el Cuadro 10 de Bonavia, 1982: 149 y el comentario en las páginas 342-343 y 409). Se trata de la chirimoya, del pallar de los gentiles, del ají, de la calabaza (Cucurbita), del camote, de la yuca, del pallar, del fréjol y del maíz.

Hay que recordar que en Tuquillo (PV35-7), al que ya nos hemos referido, en los mismos tiempos también se comió chirimoya. Un estudio de estos restos y el del sitio en cuestión ha sido publicado por Bonavia et al. (2004).

La Canavalia sp., es decir el pallar de los gentiles, se conoce desde los tiempos precerámicos (Sauer, 1964; 1968; Sauer \& Kaplan, 1969) y es casi seguro que las semillas, los fragmentos de cotiledones y de cáscara correspondan a Canavalia plagiosperma al igual que la vaina completa que se ha encontrado. Ella debió crecer en las áreas húmedas del valle o en zonas irrigadas ya que ese es el ambiente que necesita (Damp et al., 1981: 812). Es interesante recordar que Uhle encontró 
en el valle de Supe C. Plagiosperma, justamente en un contexto del Horizonte Medio 3 (Sauer \& Kaplan, 1969: 420).

En el caso del ají creemos que se trata de Capsicum frutescens, aunque sabemos que Pickersgill ha señalado la dificultad de identificar las semillas de este género; por eso ella prefiere utilizar el término «Complejo annuum-chinense-frutescens» (Pickersgill, 1984: 112 et passim). El uso del ají es muy difundido en el antiguo Perú y abundantes semillas de $C$. frutescens han sido encontradas en contextos del Horizonte Medio en el valle de Jequetepeque (Vásquez \& Rosales Tham, 2001: 25; citado con autorización de Edward Swenson).

Con respecto a la Cucurbita es decir la calabaza, es difícil saber la especie. Es de suponer que se trata de una de las cultivadas (vide Towle, 1961: 89-92) aunque bien pudo tratarse de alguna de las especies silvestres comunes en la Costa Norte (vide Hortus S. A. \& Baker Ltd., 1973: 167-171). En lo que se refiere a Ipomoea batatas y Manihot esculenta, es decir el camote y la yuca, consideramos que no es necesario ningún comentario, pues ambas son conocidas desde los tiempos precerámicos.

El pallar (Phaseolus lunatus) y el fréjol ( $P$. vulgaris) aparecen muy temprano en el Callejón de Huaylas (Bonavia, 1982: 320-321) y tampoco necesitan mayor comentario.

En lo que se refiere al maíz, recordemos que se han encontrado algunos ejemplares de las razas Proto-Confite Morocho, Confite Chavinense, Proto-Kculli y del híbrido Proto-Confite Morocho/Proto-Kculli. Esto es muy interesante en cuanto se trata de razas que aparecen en los tiempos precerámicos en el valle de Huarmey (lege Grobman, 1982) y que por razones que desconocemos se han conservado hasta el Horizonte Medio. Desafortunadamente no hay estudios que permitan conocer la evolución de las razas de maíz que se desarrollaron después de la época precerámica. En este sentido solo se ha analizado las representaciones de esta planta que han quedado en la cerámica (vg. Eubanks Dunn, 1979). Pero de todos modos la presencia de las otras razas encontradas en este yacimiento es conocida por lo menos desde los tiempos del Período Intermedio Temprano. Así la raza Proto-Alazan es característica de la Costa Norte y está representada en la cerámica mochica. El maíz Alazan fue preferido en la Costa Norte para la elaboración de la chicha (Grobman et al., 1961: 234-237). La raza Proto-Pagaladroga también ha sido representada en la cerámica Moche (Grobman et al., 1961: 202-205). La raza Huayleño, como su nombre lo indica, es característica del Callejón de Huaylas y del departamento de Ancash. Es un maíz harinoso derivado de la raza Confite Chavinense utilizado para la preparación de la kcancha (Grobman et al., 1961: 166-169). En cuanto al Rabo de Zorro es una raza derivada directamente del Proto-Confite Morocho y es característica de la zona del río Marañón y de la vertiente oriental de los Andes de los departamentos de Ancash y La Libertad. Su nombre se origina por sus mazorcas que son flexibles y más particularmente por su relación con un maíz córneo derivado del Rabo de Zorro de los valles interandinos que se ha difundido en Huarmey, Casma y Nepeña (Grobman et al., 1961: 212-215). 
También es importante el hallazgo de los fragmentos de «muñecas», que nos están señalando fenómenos de sequías que son hasta hoy uno de los problemas serios del valle de Huarmey.

Grobman considera que el hecho de haber encontrado corontas de menor longitud, que predominan junto con algunas que son más largas, puede haber sido causado por cualquiera de las siguientes posibilidades o por todas ellas en conjunto:

a) Las corontas más grandes son resultantes de segregación en curso de corontas que estaban en proceso de selección incipiente para longitud por medio de hibridaciones interraciales y su segregación. Una evidencia que esto es real se ve en la mezcla de razas emergentes tales como Proto-Pagaladroga (figs. 19e, 19f) y Proto-Alazan (fig. 19d) cuyos fenotipos son parecidos a los de las razas modernas y se pueden ver en las muestras. Hay también evidencia que aunque la raza predominante en este sitio es el Proto-Confite Morocho (figs.18e, 18f) se observan segregaciones de corontas que muestran fasciación, la cual es típica de la raza Confite Chavinense (fig. 19b) y parcialmente en la raza Proto-Kculli (fig. 19a). Eso le daría a la población o poblaciones de donde procede la muestra de la que disponemos, una amplia posibilidad de recombinación de genes cuantitativos para determinar recombinantes que podrían ser transgresivos a las medidas de las poblaciones originales más uniformes. Es importante señalar que solo 20 corontas sobre un total de 98 completas y sobre 238 si se incluyen las fragmentadas (lo que significa 8,4 \%), exhiben características tripsacoides. Ello parece ser evidencia de una introgresión, aún muy leve, de materiales genéticos que aportarían características tripsacoides propias de tipos de maíz que habrían recibido tales peculiaridades de genes de teosinte o de Tripsacum sp.

b) Las corontas más grandes podrían haber sido cosechadas en un campo diferente al de las pequeñas, que quizá fueron también preservadas para un uso diferente. Sin embargo, si se observa que 11 de ellas presentan indicios de carbonización, es probable que el consumo de granos haya sido como reventadores o como tostados. El tipo de consumo más práctico de los granos para grupos humanos como el que dejaron los residuos vegetales en el campamento que estamos estudiando, sería la forma de reventado o tostado. Por consiguiente la permanencia de tipos de mazorcas con granos reventadores como el de la muestra en cuestión, podría señalar que se privilegiaba el mantenimiento de mazorcas de tipo reventador, que están asociadas a otras más pequeñas que las emergentes de granos usados para tostado y para hacer chicha que se producen en mazorcas más grandes y cuyos granos son de mayor tamaño.

Esto le resta importancia a las afirmaciones que el tamaño de mazorca es un indicador preciso de la edad de los maíces (e.g. Bird, 1990), debido a la coexistencia de razas de diversos tipos de uso en diferentes etapas de la evolución del maíz, a pesar que se ha producido una evidente evolución de longitudes y diámetros de mazorcas a través del tiempo.

c) Puede haber habido un efecto sobre el tamaño de las mazorcas por causa de sequías. Ello se ve claramente en al menos cinco corontas con hileras abortadas posiblemente por falta de agua a las que nos hemos referido (vide supra). 
Es importante insistir sobre el hecho siguiente. El argumento más importante que esgrimió Bird (1978: 92; 1990: 833; Bird \& Bird, 1980: 330) para tratar de demostrar que los maíces encontrados en Los Gavilanes no eran precerámicos fue porque «... algunos parecen más tardíos por su tamaño más grande...» (Bird, 1990: 833). La evidencia que se presenta en este estudio con los restos variados de este yacimiento son la mejor prueba que Bird estuvo equivocado y que los argumentos que esgrimieron Bonavia \& Grobman (1999: 253-254) son válidos.

De las plantas alimenticias recolectadas solo tenemos los restos de algarrobo (Prosopis pallida). Sobre la taxonomia de esta planta hubieron algunas confusiones en el pasado; para ello remitimos al lector a los trabajos de Ferreyra (1987) y Díaz Celis (1995: 45-62). La especie $P$. pallida es común en el departamento de Ancash entre el nivel del mar y los 1500 m de altitud (Brako \& Zarucchi, 1993: 513) y es frecuente en los pedregales secos al borde del valle de Huarmey (Díaz Celis, 1995: 36). Weberbauer (1945: 264) identificó en el valle medio P. juliflora «en forma de árbol frecuente».

Nosotros lo hemos denominado como planta «estimulada», dado que por su importancia si bien no es completamente doméstica, el hombre ha influido e influye siempre más sobre ella. En este sentido es importante el estudio de Díaz Celis (1995: 73-74, 89, 103-107). P. pallida da frutos abundantes pues tiene hasta dos cosechas al año, es una planta resistente a las sequías y tiene un mesocarpio muy dulce y carnoso que lo hace aprovechable como alimento humano y como forraje (Ferreyra, 1987: 11-12; Díaz Celis, 1995: 166 et passim).

En efecto su vaina es comestible, es empleada para la preparación de algarrobina y ciertas bebidas y es utilizada en la farmacopea popular. Sus hojas son usadas como forraje. Es una fuente importante de carbohidratos y proteínas. Su leña es un combustible que tiene un valor calorífico muy alto, produce poca ceniza, escaso humo y le da un sabor muy especial a la comida. Además se aprovechan sus hojas como abono (Díaz Celis, 1995: 153-173; National Academy of Sciences, 1979: 155-156). Por la presencia de semillas y una vaina completa en excelente estado de conservación en nuestro campamento, no cabe duda que fue utilizada como alimento.

De las plantas industriales cultivadas, el algodón (Gossypium barbadense) y el mate o calabaza (Lagenaria siceraria) no necesitan mayor comentario pues se conocen y han sido usados desde los tiempos precerámicos.

La presencia de Euphorbia heterophylla no llama la atención. Es una hierba anual que crece en los campos de cultivo, al borde de las zanjas y que se conoce como huchapurga, pascua o flor de pascua de monte (Sagástegui, 1973: 272274; Hortus S.A., May \& Baker Ltd., 1973:112-113). (Hay que decir, para evitar confusiones, que para algunos el nombre común es huachapurga, v.g. Hortus S.A., May \& Baker Ltd., 1973 y Soukup, s/f [1987]: 179). Es una planta que prefiere los parajes cálidos y secos (Weberbauer, 1945: 175). Es utilizada como purgante. Si la identificación de $E$. serpens fuera correcta, se trata de una especie que tiene características parecidas a la anterior y es utilizada en la medicina casera como diurética y depurativa (Soukup, s/f. [1987]: 179). Es posible que haya sido traida al 
campamento con estos fines, dado que se ha encontrado una capsula completa, una semilla y otros restos.

El sargazo (Macrocystis pyrifera var. humboldtii) es un alga que abunda en nuestras costas y se le encuentra en grandes cantidades en las playas, de modo que su presencia en el campamento no es nada fuera de lo común. Lo que sí es evidente es que los que la trajeron no estaban familiarizados con ella, como ya se ha mencionado anteriormente (vide supra).

Si se hace una comparación con la ocupación de la misma época del sitio de Tuquillo (PV35-7; Bonavia, 1982: 233-236) se puede ver que allí se encontró también maíz, chirimoya, algarrobo y mates. Aunque es cierto que en Tuquillo hubo otras plantas que no se han encontrado en PV35-4 como Canna sp. que probablemente fue achira aunque pudo tratarse también de alguna otra especie, la palta (Persea americana), cf. Inga sp. que pudo haber sido pacay o alguna otra especie y lúcuma (Pouteria sp.). Es interesante que en este yacimiento se encontró un alga diferente, aunque conocida también como sargazo, que es la Eisenia cokeri (Alariaceae; Acleto Osorio, 1971: 76-78) que es también común en nuestras costas. La presencia de una variedad mayor de plantas en Tuquillo es lógica, dado que allí la ocupación fue durante un largo período de tiempo.

De todos modos es interesante constatar que la dieta de este grupo fue buena, pues si se juntaba al maíz, con los fréjoles y la calabaza allí se tenía la mayoría de carbohidratos, proteínas y vitaminas que se necesitaban para la nutrición, especialmente si eran consumidos acompañados con fruta como la chirimoya y condimentos como el ají. Si a esto se añadía la yuca y el camote se obtenía carbohidratos adicionales y calorías. Por su parte el algarrobo era otra planta muy nutritiva por su contenido de proteínas y aceites. Sin olvidar, por supuesto, los pescados y mariscos que eran fuentes de proteínas y grasa que comieron durante su estada cerca de la playa, y que pasaremos a discutir inmediatamente.

Si se observa la Tabla 9, se podrá ver que los moluscos que fueron consumidos mayormente fueron el choro común o mejillón (Aulacomya ater) y el chorito (Perumytilus purpuratus) mientras que el resto lo fue en cantidades mínimas. El primero vive en el sublitoral rocoso entre los 4 y $30 \mathrm{~m}$ de profundidad y el segundo en el medio litoral rocoso, en la línea entre el alta y la baja marea (Peña, 1982: 183-184). Son fáciles de recolectar.

Los restos de quitones, básicamente barquillos y barbones (Enopolochiton niger y Acanthopleura echinata) merecen un comentario aunque fueron recogidos en cantidades pequeñas. Por otro lado y como ya se ha explicado, treinta barquillos son completos y solo les falta el pie y el contenido visceral. Aunque hay que señalar que en todos ellos han quedado restos de estos. En primer lugar hay que decir que si se tiene experiencia y un instrumento adecuado, se puede recolectar a estos moluscos en cantidades importantes, pero por el número encontrado definitivamente este no ha sido el caso de los ocupantes del campamento. Y luego se ve claramente que no tenían familiaridad con estos moluscos, pues no supieron comerlos eficientemente, y no aprovecharon toda la parte comestible. 
Los remanentes de crustáceos represantan cantidades tan bajas que demuestran que no fueron recogidos con fines concretos, sino posiblemente por curiosidad y lo mismo se puede decir del único muymuy y del fragmento de la estrella de mar.

Los escasos huesos de peces pueden ser interpretados de dos maneras, o los comieron solo ocasionalmente o pescaron, comieron lo indispensable y se llevaron casi todo. Consideramos que visto el conjunto de pruebas que tenemos por los otros restos animales encontrados, la segunda posibilidad es muy difícil de aceptar. Nos inclinamos a creer que los ocupantes del campamento no fueron personas acostumbradas a explotar los recursos marinos de modo que no sabían pescar, y los pocos remanentes de peces indican un uso ocasional en su alimentación, cuando viviendo cerca de la playa debió ser exactamente lo contrario. Los pocos huesos de aves indican también un uso fortuito o que simplemente recogieron animales muertos en la playa.

El único hueso de Cetacea muy probablemente corresponde a delfín y seguramente fue recogido en la playa. Dado que el hueso encontrado muestra huellas que parecen ser de mascado y fracturas que son intencionales, es probable que el cetáceo o parte de él ha sido encontrado muerto en la orilla del mar.

Los peces fueron cocidos muy probablemente sobre las brasas al igual que el resto de alimentos.

Con respecto al polen que estaba en los excrementos de llama, como se puede apreciar en la Tabla 10, predomina en proporciones importantes el de Asteraceae de espina corta (46,5\% y 48,8 \%); le sigue en importancia un polen que no se ha podido identificar y que hemos denominado Desconocido «A» con 20,2 \% y 15,5\% y luego en tercer lugar el de Poaceae con $11 \%$ y 9,5\%. Es importante recordar que en este caso no se ha incluido al maíz, cuyo polen ha sido identificado por separado y que representa tan solo el 2,2 \% y 1,3\%. Todo el resto está presente en porcentaje muy bajo.

En el caso de las Asteraceae EC se hace muy difícil suponer qué género puede estar representado, ya que ningún sector de la flora peruana queda exento de esta gran familia, de la cual viven en el Perú 204 géneros (Soukup, s/f [1987]: 71). Los granos de Asteráceas de espina corta representan polen aéreo que podría corresponder al de Ambrosia. A. peruviana conocida como marco o altamisa y otros nombres; es frecuente en la costa norperuana a los bordes de las chacras así como en los terrenos incultos con vegetación herbácea o leñosa baja; invade frecuentemente los rastrojos y campos abandonados y solo ocasionalmente los cultivos (Sagástegui Alva, 1973: 420-422). De todos modos estas Asteráceas son un alimento importante para las bestias junto con otros miembros y granos que no se pueden identificar de Rosaceae, aunque estas aparecen en porcentaje sumamente bajo (1 \% y $2 \%$ ). Dado que estos y otros tipos son componentes comunes de zonas de vegetación del valle medio y alto, su presencia no sorprende. Es normal suponer a una llama pastando estas plantas y similares.

En lo que se refiere a los granos de Poaceae que no corresponden a maíz, hay que tomar en cuenta que con la excepción de este, virtualmente todos los granos de polen de esta familia no se pueden distinguir. Hay que considerar también que 
las plantas de esta familia son polinizadas por el viento y su polen es usualmente considerado como mayormente representativo de las lluvias de polen de vegetación natural. Es además una familia muy amplia y es difícil tratar de sugerir los géneros a los que puede pertenecer el polen en cuestión. De hecho las muestras pueden representar plantas silvestres de los graminales playeros marítimos o de los montes ribereños en los valles costeros.

Es poco probable que la llama haya sido llevada a pacer en los campos de maíz. La presencia de polen de esta planta puede indicar que partes de ella, como las hojas y los tallos, hayan sido dadas como alimento al animal.

Salicornia sp. es un miembro de las suculentas de la familia Chenopodiaceae que son tolerantes de la sal; es un arbusto común en las playas marítimas y se le encuentra muy cerca del campamento en cuestión. Se ha sugerido (Jones \& Bonavia, 1992: 841-842) que haya podido ser usado como alimento para las llamas. Sin embargo en nuestro caso no se ha encontrado trazas discernibles en los restos macro y el porcentaje de polen de Cheno/Am es relativamente bajo en las muestras. Se deduce, pues, que Salicornia no ha sido un componente dietético significativo para el animal.

Es interesante que en Tuquillo (PV35-7) en el estrato correspondiente al Horizonte Medio se encontró también estiércol de llama (Bonavia, 1982: 236), lo que indica que el uso de estos animales en la costa ha sido común. Esta es una costumbre que en Huarmey se inicia en la época Precerámica (Bonavia, 1982: 225-226).

Si se observa la Tabla 10 se podrá ver que la mayoría de las plantas identificadas son anemófilas, con excepción de las Cucurbitáceas que son zoofilas, de las Malváceas que son zoofilas/entomófilas y de las Rosáceas que son anemófilas/ zoofilas. De todas ellas, la mayoría polinizan todo el año, con excepción de las Rosáceas y de las Cucurbitáceas que lo hacen en primavera o en otoño. Pero en conjunto son todas plantas con abundante polinización.

Hay que señalar que el polen de las plantas anemófilas y zoofilas puede ser atrapado en el agua que tomaban o inhalaban accidentalmente o que estaba depositado sobre las plantas que se comían; y que el polen de Cheno/Am es llevado por el viento en gran cantidad en la estación de florecimiento (Bryant, 1974: 416). De modo que su presencia en el excremento de la llama es normal.

En lo que se refiere a los restos polínicos encontrados en los coprolitos humanos que se puede ver en la Tabla 11, se aprecia que los componentes de polen no arbóreo que incluyen Cheno/Am, Asteráceas, Potamogetonáceas y Poáceas, todas en proporciones bajas, sugieren que se trata de contaminación ambiental de la superficie de los alimentos, más que de uso doméstico de plantas emparentadas. Merece señalar que en el caso de Potamogetonáceas se ha llegado solo hasta la identificación de cf. Potamogeton sp. Es una planta cosmopolita de la que existen 100 especies que habitan en las aguas estancadas y corrientes; aparentemente en el Perú se conocen solo 4 (vide Usher, 1974: 480; Soukup, s/f [1987]: 335), aunque curiosamente Weberbauer (1945: 21) ha identificado el género solo en las zonas pantanosas al sur de Lima. No conocemos usos de esta planta, salvo que parece que se utiliza en medicina popular para el tratamiento de heridas y 
contusiones (Bernardino Ojeda, Comunicación personal a Glendon Weir, 1978 el cual la ha transmitido a Bonavia). Sin embargo, se trata de un uso externo que no explicaría la presencia de polen en el coprolito. Pero sabemos que algunas especies son utilizadas como alimento de emergencia en otras partes del mundo (Usher, 1974: 480), de modo que esto merece mayor investigación.

Entre este polen no arbóreo hay un tipo que aparece en proporciones que son las más altas de las muestras (90 \% y $100 \%$ ) y que en consecuencia debe tener importancia y queremos comentarlo a parte. Nos referimos a los granos que pertenecen a la familia Protaceae y todo indica que se trata de cf. Oreocallis sp. En los Andes peruanos las Protáceas tienden a preferir los montes bajos y los pajonales y su hábitat es entre los 1000 y 3600 metros de altitud (Weberbauer, 1945: 159; Soukup, s/f [1987]: 298). En el Perú se conocen dos especies de este género, $O$. grandiflora y $O$. mucronata y la segunda se usa en medicina popular (Soukup, s/f [1987]: 298-299). No sabemos cómo ha podido llegar esta planta hasta PV35-4. Es probable que fue traida de las partes altas del valle de Huarmey con algún fin exótico que desconocemos. Esto no debe llamarnos la atención, ya que tenemos la evidencia que restos de una planta de la misma familia, Roupala ferruginea, ha sido encontrada en Ancón (vide Towle, 1961: 35) .

Las esporas de Pteridofitas (criptógamas vasculares) se explican, pues estas plantas se encuentran en las lomas costeras y en las vertientes occidentales de los Andes Centrales (Weberbauer, 1945: 260, 332). Lo mismo se puede decir de las esporas de hongos que, dada la humedad de la zona costera, son normales.

Los otros restos que se han identificado son carbón en las tres muestras, fibras vegetales de dicotíledoneas y monocotiledóneas en una y algunas semillas de Rosaceae en el Coprolito n. ${ }^{\circ}$ 51. Los restos de carbón son lógicos, en cuanto se cocinaba sobre las brasas. Sobre las monocotiledóneas y las dicotiledóneas es difícil señalar algunas plantas, pues ambas clases son muy difundidas en nuestra costa (lege Sagástegui Alva, 1973).

Las semillas de Rosaceae merecen un comentario, pues se trata de un hallazgo difícil de interpretar. En el Perú las subfamilias más conocidas (Spiraeoideae, Rosoidae y Prunoidae) son todas de altura y no tienen utilidad económica (vide Weberbauer, 1945: 166-168). De estas plantas la única que se conoce a nivel arqueológico es la Kageneckia lanceolata, cuya madera ha sido utilizada para la construcción de puentes colgantes y para hacer bastones. Además, la infusión de su corteza amarga y de sus hojas es usada a nivel popular como remedio para la fiebre. Esta planta es conocida como lloque y uritumicuna y su presencia es bastante frecuente en las tumbas prehispánicas costeñas, en forma de porras o macanas (vide Towle, 1961: 41; Soukup, s/f [1987]: 232). En la costa hoy en día hay dos Rosáceas que son utilizadas en la medicina folklórica, son Esperomeles sp., conocida vulgarmente como rumilanche y se emplea como abortivo y Rubus sp. cuyo nombre vulgar es zarzamora (de la que en el Perú hay 16 especies) y cuya infusión es utilizada para curar la diabetes (Vásquez Núñez, 1974: 41, 46). De modo que podemos suponer que las semillas halladas en el coprolito n. ${ }^{\circ} 51$ pueden indicar uso de madera y que con ella se trajo accidentalmente alguna 
semilla, o uso intencional de estas para fines medicinales. En todo caso es una planta que ha sido traída de alguna zona alta lejana, muy probablemente con fines concretos.

Los otros restos que se pudieron identificar son huesos y plumas de aves, huesos y escamas de peces, huesos y pelos de mamíferos; además se encontraron fragmentos de conchas univalvas y bivalvas (Tabla 12) que son normales, dada la dieta que han tenido los ocupantes del campamento.

Si se confrontan las evidencias botánicas halladas in situ, en el mismo contexto de los coprolitos humanos, con los restos encontrados en estos, se nota perfectamente que los últimos no reflejan más que parcialmente la dieta de los individuos que vivieron allí. En efecto, los remanentes marinos y de maíz se han identificados en ambos, pero la abundante cantidad de camote (Ipomoeas batatas), de yuca (Manihot esculenta), de ají (Capsicum sp.), de fréjoles (Phaseolus vulgaris), pallares (Phaseolus lunatus) y pallares de los gentiles (Canavalia plagiorperma) que ha sido encontrada en los residuos de cocina, no aparece en los coprolitos. Pero ello es normal ya que en este caso la muestra no es significativa dado que no cabe la menor duda que las tres heces humanas halladas cerca del fogón no pueden representar las deposiciones del grupo que vivió allí, por más reducido que este haya sido.

Un hecho que llama la atención es que los coprolitos estaban cerca del fogón. Es decir se defecaba en el área de vivienda y cerca del lugar donde se preparaba la comida. Esto es algo que, hasta donde sabemos, no ha sido analizado hasta ahora por lo menos en el Perú. Es importante recordar, sin embargo, que en el yacimiento precerámico Los Gavilanes (PV35-1) también se encontraron dos coprolitos cerca de un fogón y cuatro más estaban entre las cenizas del fogón del edificio público, aunque es cierto que en este caso ellos podrían ser posteriores (Bonavia, 1982: 226). Sin embargo, hay una evidencia similar más. En el villorrio precerámico Paloma, Engel (1980: 108) anotó:

«Se debe notar que excrementos humanos fueron encontrados sobre los pisos de vivienda de las casas».

Este es el mejor ejemplo para recordar que un arqueólogo debe despojarse de los conceptos de su cultura en sus investigaciones.

El hallazgo de arena en los coprolitos no debe llamar la atención. Es conocido que residuos de arena y polvo se han encontrado con frecuencia en heces arqueológicas y ellos pueden ser debidos tanto al contacto de estas con el suelo, como a la ingestión casual de arena y polvo con las comidas o intencionalmente (Reinhard \& Bryant, 1992: 257). En el caso peruano Callen \& Cameron (1960: 39) lo observaron en los restos fecales de Huaca Prieta. Sabemos que en los coprolitos provenientes de la región de Ayacucho en la Sierra Central y de Paloma en la Costa Centro Meridional se encontraron también restos parecidos (lege Weir \& Bonavia, 1985: 96). En Los Gavilanes se registró el mismo fenómeno, pero además de la arena había tierra (Weir \& Bonavia, 1985: 96, 98, 106, 109). Weir \& Bonavia (1985: 120) han planteado la hipótesis que, en realidad, esta arena y esta 
tierra no fueron accidentales sino que representan una costumbre para nosotros desconocida. En el caso de nuestro campamento pareciera que este no fuera el caso y que la arena es consecuencia, como ya se dijo, de la ingestión de moluscos y otros restos marinos sin lavar y que siempre contienen arena.

Pero queremos insistir que el valor de los análisis de los coprolitos humanos en este caso no es representativo por la pequeña cantidad. Para tener datos más concretos habría que buscar el resto de defecaciones, una parte de las cuales podría estar en la zona no excavada del sitio, aunque posiblemente la mayor parte ha sido dejada lejos del yacimiento.

La presencia de Trichuris trichiura que se conoce con el nombre genérico de tricocéfalo, en dos de los coprolitos estudiados nos da la certeza que estos restos fecales son humanos (Reinhard, 1990: 155) y sabemos que las especies que parasitan a los animales son diferentes de las del hombre. Se trata de un parásito que se transmite fecalmente, es muy común y pasa habitualmente inadvertido, tan es así que muchas personas los revelan en sus materias fecales sin presentar trastornos mórbidos visibles. Sin embargo, a veces, cuando el parasitismo es muy intenso, se pueden producir síntomas variables. En las infecciones intensas entre otros hay diarrea mucosa más o menos profusa, a veces con sangre, lo que no parece haber sido el caso del o los que depositaron estas heces (Parodi \& Alcaraz, 1946: 379-384; Faust et al., 1979: 275). Las condiciones favorables para que los huevos no embrionados y evacuados de este tricocéfalo se desarrollen son el suelo húmedo y caliente, al resguardo de la luz directa (Faust et al., 1979: 274) que son las condiciones de los valles costeros peruanos. La infección se adquiere al ingerir estos huevos, obtenidos directa o indirectamente del suelo (Faust et al., 1979: 274). El tricocéfalo humano es cosmopolita y conocemos muchos casos de esta parasitosis en tiempos prehispánicos en América (v.g. Ferreira et al., 1980) de modo que no llama la atención.

En el caso de ooquistes de Cryptosporidium, estos han sido reconocidos en restos fecales extraidos de 39 cadáveres prehispánicos (Allison et al., 1999). Desafortunadamente en el informe no se indica ni los métodos de identificación que fueron empleados, ni los sitios de los que provenían las muestras, como tampoco la fecha o asociación cultural de cada una de ellas (lege Ortega \& Bonavia, 2003: 636). Lo único que indican Allison et al. (1999: 606) es que «[e]ntre dos gramos a 3-g de muestra de heces momificadas [sic!] secas de 39 nativos Andinos Americanos [sic!] que murieron hace 500 a 3000 años...» fueron estudiadas (Allison et al., 1999: 606). Señalan que Cryptosporidium parvum fue identificado en 15 muestras.

Dado que sabemos que Allison ha trabajado en la Costa Sur, podemos suponer que las muestras proceden de dicha área. A juzgar por las fechas que los autores indican (Allison et al., 1999: 606) lo único que se puede deducir es que oscilan probablemente entre fines del Período Inicial y el Horizonte Tardío. Más no se puede inferir. Trabajos de esta naturaleza no tienen ningún valor científico.

Hay que recordar que la cryptosporidiosis es una enfermedad cosmopolita. Es un protozoo coccidia que parasita el aparato digestivo del hombre y de un gran 
número de animales. Puede transmitirse de hombre a hombre, de hombre a animales y de animales a hombre. Además de la contaminación fecal del medio ambiente puede producirse la diseminación por medio del agua, de los alimentos e inclusive del aire, a través de las manos o de los objetos contaminados. De modo que su contagio en tiempos prehispánicos debió ser fácil. Es interesante en cuanto el patógeno se encuentra frecuentemente en las poblaciones costeras actuales del Perú y causa diarrea en humanos y animales. La presentación clínica en niños, ancianos e individuos inmunocomprometidos es más severa y se caracteriza por diarrea aguda que generalmente dura hasta un mes (Lege Ortega \& Bonavia, 2003). Queremos insistir, sin embargo, sobre lo que se dijo al tratar la infestación de tricocéfalo (vide supra), que a juzgar por las muestras encontradas, no mostraban evidencia de diarrea, pues las heces estaban bien formadas. En este sentido es importante que Allison et al. (1999: 608) han observado también que las muestras fecales analizadas procedían de:

«... heces formadas, sugiriendo que los organismos [ellos se refieren a Cryptosporidium y Giardia] no estaban produciendo malestar diarréico en el paciente 14 al tiempo de su muerte...».

Consideramos que la gran cantidad de materiales de este pequeño sitio que se ha podido identificar y estudiar, demuestra la riqueza de los yacimientos peruanos costeños, su excepcional conservación y señala la urgente necesidad de ampliar las investigaciones en asentamientos de vivienda común que han sido descuidadas en la arqueología peruana pero que son indispensables si se quiere conocer más sobre la vida latu sensu en aquellos tiempos.

\section{Agradecimientos}

Debemos recordar en primer lugar a Richard Ford que nos apoyó en la investigación botánica haciendo posible la interveción de Laura W. Johson-Kelly en nuestro equipo de trabajo y a Vaughn M. Bryant que nos permitió la realización de los estudios palinológicos en los laboratorios de Texas A\&M University.

Nuestro finado amigo Timothy Plowman colaboró con la identificación de algunas muestras, lo mismo que Emma Cerrate de Ferreyra y Lawrence Kaplan. Mario Peña nos guió en el estudio malacológico, lo mismo que hizo Humberto Guerra con respecto a la parte parasitológica.

Aurelio Bonavia, siendo aún estudiante de secundaria, ayudó a ordenar y midió los restos de maíz. Elmo León colaboró en la preparación de nuestros cuadros.

A todas estas personas nuestro más profundo agradecimiento que se hace extensivo a cualquiera que en forma involuntaria hayamos podido olvidar.

14 Para evitar confusión hay que aclarar que los autores llaman con este nombre a los cadáveres prehispánicos 


\section{Referencias citadas}

ACLETO OSORIO, C., 1971 - Algas Marinas del Perú de Importancia Económica, 85 pp.; Lima: Universidad Nacional Mayor de San Marcos, Museo de Historia Natural «Javier Prado», Departamento de Botánica, Perú.

ALLISON, M. J., BERGMAN, T. \& GERSZTEN, E., 1999 - Further Studies on Fecal Parasites in Antiquity. American Journal of Clinical Pathology, 112: 605-609.

BIRD, R. Mck., 1978 - Archaeological maize from Peru. Maize Genetics Cooperation News Letter, 52: 90-92.

BIRD, R. Mck., 1990 - What are the Chances of Finding Maize in Peru Dating Before 1000 B.C.? American Antiquity, 55: 325-332.

BIRD, R. Mck. \& BIRD, J. B., 1980 - Gallinazo maize from the Chicama Valley, Peru. American Antiquity, 54 (2): 325-332

BONAVIA, D., 1982 - Los Gavilanes. Mar, desierto y oasis en la historia del hombre, 512 pp.; Lima: Corporación Financiera de desarrollo COFIDE, Instituto Arqueológico Alemán, Perú.

BONAVIA, D. \& GROBMAN, A., 1999 - Revisión de las pruebas de la existencia de maíz precerámico de los Andes Centrales. Boletin de Arqueología PUCP, 3: 239-261.

BONAVIA, D., OCHOA, C. M., TOVAR, S. O. \& CERRÓN PALOMINO, R., 2004 Archaeological Evidence of Cherimoya (Annona cherimolia Mill.) and Guanabana (Annona muricata) in Ancient Peru. Economic Botany, 58: 509-522.

BRYANT Jr., V. M., 1974 - Prehistoric diet in Southwest Texas: the coprolite evidence. American Antiquity, 39: 407-420.

BRAKO, L. \& ZARUCCHI, J. L., 1993 - Catalogue of the Flowering Plants and Gymnosperm of Peru: Catálogo de las Angiospermas y Gimnospermas del Perú. St. Louis, Monographs in Systematic Botany from the Missouri Botanical Garden, 45: i-xl, 45-1286; Missouri.

CAILLEUX, A. \& TAYLOR, G. s/f - Code Expolaire/ Notice sur le Code Expolaire; París: Éditions N. Boubbée \& Cie. France.

CALLEN, E. O. \& CAMERON, T. W. M., 1960 - A Prehistoric diet revealed in coprolites. The New Scientist, VIII: 35-37, 39-40.

DAMP, J. E., PEARSALL, D. M. \& KAPLAN, L. T., 1981 - Beans for Valdivia. Science, 212: 811-812.

DÍAZ CELIS, A., 1995 - Los Algarrobos, 207 pp.; Lima: CONCYTEC, Perú.

EMERY, I., 1980 - The Primary Structures of Fabrics, an Illustrated Classification, XXVI + 341 pp.; Washington D.C.: The Textile Museum. U.S.A.

ENGEL, F. A., (ed.), 1980 - Prehistoric Andean Ecology. Man, Settlement and Environment in the Andes, 116 pp.; New York: Distributed by Humanities Press for The Department of Anthropology, Hunter College, City University of New York. U.S.A.

EUBANKS DUNN, M., 1979 - Ceramic depictions of maize: A basis for classification of prehistoric races. American Antiquity, 44: 757-774.

FAUST, E. C., RUSSEL, P.F. \& JUNG, R. C., 1979 - Parasitología clínica, VIII + 888 pp.; México: Salvat Mexicana de Ediciones, S.A. de C.V. México.

FERREIRA, L. F., ARAúJO, A. J. G. \& CONFALONIERI, U. E. C., 1980 - The finding of eggs and larvae of parasitic helminths in archaeological material from Unai, Minas Gerais, Brazil. Transactions of the Royal Society of Tropical Medicine and Higiene, 74: 798-800. 
FERREYRA, R., 1987 - Estudio sistemático de los algarrobos de la costa norte del Perú, 31 pp.; Lima: Ministerio de Agricultura, Instituto Nacional Forestal y de Fauna, Dirección de Investigación Forestal y de Fauna. Auspiciado por el Centro Internacional de Investigaciones para el Desarrollo del Canada (CIID-Canada), CONCYTEC, Perú.

GREENBLAT, I. M., 1968 - A possible selective advantage of plant color at high altitudes. Maize Genetic Cooperation Newsletter, 42: 144-145.

GROBMAN, A., 1982 - Maíz (Zea mays). In: Los Gavilanes. Mar, desierto y oasis en la historia del hombre (D. Bonavia): 157-179; Lima: Corporación Financiera de desarrollo COFIDE, Instituto Arqueológico Alemán, Perú.

GROBMAN, A., SALHUANA, W., SEVILLA, R. in collaboration with MANGELSDORF, P. C., 1961 - Races of Maize in Peru, IX + 374 pp.; Washington: National Academy of Sciences-National Research Council (Publication 915).

HORTUS S.A., May \& BAKER Ltd., 1973 - Manual de malezas en el Perú, comunes en caña de azúcar, 224 pp.; Lima: Servicio de Copias S.C.R.L. Perú.

ISHIDA, E., AKI, K., YAZAWA, T., IZUMI, S., SATO, H., KOBORI, I., TERADA, K. \& OBAYASHY, T., 1960 - Andes. The Report of the University of Tokyo Scientific Expedition to the Andes in 1958 (Report 1), 528 pp.; Tokyo: Bijutsu Shuppan Sha, Japon.

JONES, J. G. MS., 1990 - Results of the Analysis of Palynological Investigation of Camelid Feces from Peru, 9 pp. Manuscrito en los archivos de Duccio Bonavia.

JONES, J. G., 1993 - Analysis of pollen and phytoliths in residue from a Colonial Period ceramic vessel. In: Current Research in Phytolith Analysis: Applications in Archaeology and Paleoecology (D. M. Pearsall \& D. R. Piperno, eds.), Vol. 10: 31-35; Philadelphia: The University Museum of Archaeology and Anthropology, University of Pennsylvania. U.S.A. MASCA Research Papers in Science and Archaeology.

JONES. J. G. \& BONAVIA, D., 1992 - Análisis de coprolitos de llama (Lama glama) del Precerámico Tardío de la costa central del Perú. Bulletin de I'Institut Français d'Études Andines, 21: 835-852.

MARTIN, P. S., 1963 - The last 10,000 years. A fossil pollen record of the American Southwest, 87 pp.; Tucson: University of Arizona Press, U.S.A.

MENZEL, D., 1968 - La Cultura Huari. Las Grandes Civilizaciones del Antiguo Perú, Tomo VI, 223 pp.; Lima: Compañía de Seguros y Reaseguros Peruano Suiza S.A., Perú.

NATIONAL ACADEMY OF SCIENCES, 1979 - Tropical Legumes: Resources for the Future, VIII + 332 pp.; Washington: National Academy of Sciences, U.S.A.

ORTEGA, Y. R. \& BONAVIA, D., 2003 - Cryptosporidium, Giardia, and Cyclospora in Ancient Peruvians. Journal of Parasitology, 89: 635-636.

PARODI, S. E. \& ALCARAZ, R. A., 1946 - Manual práctico de parasitología, 764 pp.; Buenos Aires: Vázquez, Argentina.

PATRUCCO, R., TELLO, R. \& BONAVIA, D., 1983 - Parasitological studies of coprolites of pre-hispanic peruvian populations. Current Anthropology, 24: 393-394.

PEÑA, M., 1982 - Mollusca, Arthropoda, Echinodermata. In: Los Gavilanes. Mar, desierto y oasis en la historia del hombre (D. Bonavia): 183-190; Lima: Corporación Financiera de desarrollo COFIDE, Instituto Arqueológico Alemán, Perú.

PICKERSGILL, B., 1984 - Migrations of Chili Peppers, Capsicum spp., in the Americas. In: Pre-Columbian Plant Migration (D. Stone, ed.): 105-123; Cambridge: Harvard University Press., U.S.A. Papers of the Peabody Museum of Archaeology and Ethnology, Harvard University Vol. 76.

PURSEGLOVE, J. W., 1969 - Tropical crops. Dicotyledons 1. Vol. 1, XIV + 332 pp.; London: Longmans Green and Co. Ltd. Inglaterra. 
REINHARD, K. J., 1990 - Archaeoparasitology in North America. American Journal of Physical Anthropology, 82: 145-163.

REINHARD, K. J. \& BRYANT, Jr., V. M., 1992 - Coprolites Analysis. A Biological Perspective on Archaeology. In: Archaeological Method and Theory (M. B. Schiffer, ed.): 245288; Tucson \& London:The University of Arizona Press, U.S.A.

SAGÁSTEGUI ALVA, A., 1973 - Manual de las Malezas de la Costa Peruana, 480 pp.; Trujillo: Talleres Gráficos de la Universidad Nacional de Trujillo, Perú.

SAN MARTíN, F. \& BRYANT, F. C., 1987 - Nutrición de los Camélidos Sudamericanos: Estado de nuestro conocimiento, 67 pp.; Lima, Lubbock: Facultad de Medicina Veterinaria, Instituto Veterinario de Investigaciones Tropicales y de Altura, Universidad Nacional Mayor de San Marcos; Department of Range and Wildlife Management, College of Agricultural Sciences, Texas Tech University. Artículo Técnico T-9-505. Programa Colaborativo de Apoyo a la Investigación en Rumiantes Menores.

SAN MARTíN, F., PFISTER, J. A., ROSALES, L., FARFÁN, R. \& HUISA, T., 1989 Comportamiento alimenticio al pastoreo de llamas, alpacas y ovinos en los Andes del Perú. In: Investigaciones sobre pastos y forrajes de Texas Tech University en el Perú, (F. San Martín \& F. C. Bryant, eds.), Vol. V: 97-111; Lubbock: Texas Tech University. Rumiantes menores, Programa Colaborativo para el Apoyo a la Investigación in collaboration with the United States Agency for International Development. Grant DSAN/XII-G-0049 and Instituto Nacional de Investigación y Promoción Agropecuaria, Perú. Technical Article T-9-584 of the College of Agricultural Sciences.

SAUER, J. D., 1964 - Revision of Canavalia. Brittonia, 16: 106-181.

SAUER, J. D., 1968 - Ethnobotany of Canavalia in the New World. In: Actas y Memorias, XXXVII Congreso Internacional de Americanistas, Vol. II: 507-508; Buenos Aires: Librart S.R.L., Argentina. República Argentina, 1966.

SAUER, J. \& KAPLAN, L., 1969 - Canavalia beans in American prehistory. American Antiquity, 34: 417-424.

SOUKUP SDB, J., s/f [1987] - Vocabulario de los nombres vulgares de la flora peruana y catálogo de los géneros, 436 pp.; Lima: Editorial Salesiana, Perú.

SCHWEIGGER, E., 1964 - El litoral peruano, 414 pp.; Lima: Universidad Nacional «Federico Villarreal», Perú.

TABíO, E. E., 1977 - Prehistoria de la Costa del Perú, 268 pp.; La Habana: Academia de Ciencias de Cuba, Cuba.

THOMPSON, D. E., 1966 - Archaeological Investigation in the Huarmey Valley, Peru. In: Actas y Memorias, XXXVI Congreso Internacional de Americanistas, Vol. 1: 541-548; Sevilla, España. España, 1964.

TOWLE, M. A., 1961 - The Ethnobotany of Pre-Columbian Peru, 180 pp.; New York: Wenner-Gren Foundation for Anthropological Research, Incorporated, U.S.A.

USHER, G., 1974 - A Dictionary of Plants Used by Man, 619 pp.; New York: Hafner Press, A Division of Macmillan Publishing Co., Inc., U.S.A.

VÁSQUEZ NúÑEZ, L., 1974 - Algunos aspectos actuales sobre el uso de plantas medicinales en la costa peruana. Anales Científicos, 17: 32-52.

VÁSQUEZ SÁNCHEZ, V. F. \& ROSALES THAM, T., MS., 2001 - Análisis del material orgánico del Proyecto Pacasmayo. Informe final.

WeBerbAuER, A., 1945 - El Mundo Vegetal de los Andes Peruanos. Estudio Fitogeográfico, 776 pp.; Lima: Estación Experimental Agrícola de La Molina. Dirección de Agricultura. Ministerio de Agricultura, Perú. 
Historia de un campamento del Horizonte Medio de Huarmey, Perú (PV35-4)

WEIR, G. \& BONAVIA, D., 1985 - Coprolitos y dieta del Precerámico tardío de la costa peruana. Bulletin de l'Institut Français d'Études Andines, XIV: 85-140.

YACOVLEFF, E. \& HERRERA, F. L., 1934 - El mundo vegetal de los antiguos peruanos. Revista del Museo Nacional, III: 241-322. 